\title{
CEsifo \\ WORKING

\section{The Determinants of Islamophobia - An Empirical Analysis of the Swiss Minaret Referendum}

Olga Orlanski, Günther G. Schulze 


\section{Impressum:}

CESifo Working Papers

ISSN 2364-1428 (electronic version)

Publisher and distributor: Munich Society for the Promotion of Economic Research - CESifo $\mathrm{GmbH}$

The international platform of Ludwigs-Maximilians University's Center for Economic Studies and the ifo Institute

Poschingerstr. 5, 81679 Munich, Germany

Telephone +49 (o)89 2180-2740, Telefax +49 (o)89 2180-17845, email office@cesifo.de

Editors: Clemens Fuest, Oliver Falck, Jasmin Gröschl

www.cesifo-group.org/wp

An electronic version of the paper may be downloaded

- from the SSRN website: $\quad$ www.SSRN.com

- from the RePEc website: $\quad$ www.RePEc.org

- from the CESifo website: www.CESifo-group.org/wp 


\title{
The Determinants of Islamophobia - An Empirical Analysis of the Swiss Minaret Referendum
}

\begin{abstract}
We analyze the determinants of Islamophobia using the only nation-wide anti-Islam referendum ever, which was held in Switzerland in 2009 and led to the prohibition of minarets. We find economic, environmental, and cultural factors as well as the presence of Muslims to determine voting behavior. Approval rates for the bill rise with unemployment and decrease with education, income, and the attractiveness of the location. Approval is higher in rural areas, in municipalities with a higher share of men, and in the Italian and German speaking parts of Switzerland. It is higher in municipalities with a higher share of Muslims, which strongly supports the 'religious threat' hypothesis. We compare the voting behavior in the minaret referendum with the referendum "for democratic naturalizations", held in 2008, in order to disentangle determinants of Islamophobia from those of xenophobia. We show that our results are robust to the estimation with ecological inference.
\end{abstract}

JEL-Codes: D720, D780, J150.

Keywords: referendum, minaret referendum islamophobia, xenophobia, ecological fallacy.

\author{
Olga Orlanski \\ Caritas \\ Freiburg / Germany \\ olga.orlanski@caritas.de
}

\author{
Günther G. Schulze* \\ Albert-Ludwigs University Freiburg \\ Freiburg / Germany \\ guenther.schulze@vwl.uni-freiburg.de
}

*corresponding author

October 14, 2017

We are grateful to Bernd Fitzenberger and participants of the European Public Choice Conference for valuable comments. We especially thank the members of the Swiss Federal Statistical Office (BFS) Madeleine Schneider, Corinne Di Loreto, Patricia Zocco, Paul Roethlisberger, and Marion Besancet as well as the members of the State Secretariat for Economic Affairs (SECO) Jonathan Gast, Clito Roffler, and others for their efforts to make available the data on which this study is based. The usual disclaimer applies. 


\section{Introduction}

Mistrust or aversion against ethnic or religious groups has severe economic consequences. A large literature finds that ethnically divided societies provide fewer and less productive public goods (e.g. Alesina et al. 1999, Miguel and Gugerty 2005) and, as a consequence, grow at lower rates (Easterley and Levin 1997, Alesina et al. 2003). Montalvo and ReynalQuerol (2005) find that religious polarization negatively affects growth through a reduction in investment, an increase in government consumption and an increased likelihood of civil conflict. One central reason behind these results is the lack of trust and cooperation between different ethnicities and members of different religious beliefs that exacerbates collective action problems (Habyarimana et al. 2007). Zak and Knack (2001) show that societies with low trust levels grow more slowly. Much of the empirical research has centered on societies of developing countries, notably in Africa; some of the work has analyzed the US.

Yet, ethnic and religious cleavages have become much more virulent in Europe as well. Immigration and refugee flows from conflict areas as well as higher fertility rates have led to an increasing share of residents with foreign background, both as citizens and as foreigners. Many of the residents with immigration background are Muslims, while there are hardly any Muslims in Europe without immigration background. The share of Muslims amounted to $4.4 \%$ in Germany (2015), to 7-9 \% in France (2015), to $5 \%$ in the Netherlands (2009), and to $5.1 \%$ in Switzerland (2015). ${ }^{1}$ Especially after the attacks of $9 / 11$, concerns have grown about the increasing influence of Islam, in particular the radical Islam, on Western societies. This has led to strong resentments against Muslim immigrants in Europe as a recent PEW Research Center report suggests (Wike et al. 2016). The political fallout of these and related resentments has been a rise of right-wing populist parties that strongly oppose immigration and Islam and emphasize national values throughout Europe. ${ }^{2}$

\footnotetext{
${ }^{1}$ All figures taken from CIA world factbook, accessed June 8, 2017.

${ }^{2}$ Examples, including the vote shares in the most recent parliamentary elections are Freiheitliche Partei Österreichs in Austria (20.5 \%, 2013), Partij voor de Vrijheid in The Netherlands (13.3 \%, 2017), Front National in France (13.2 \%, 2017), Vlaams Belang in Belgium (3.7 \%, 2014), Sverigedemokraterna in Sweden $(12.9$ \%, 2014), Perussuomalaiset, Finns Party (earlier the True Finns Party) in Finland (17.6
} 
While economic and political effects of religious and ethnic cleavages are well understood at the macro level, much less is known about the the determinants of individual aversion against religious minorities, Muslims in Europe in particular. There are two main reasons for this. First, opinion polls are notoriously incorrect as they suffer from untruthful answers to sensitive questions (e.g. Tourangeau and Yan 2007). Certainly, attitudes towards Muslims are a sensitive issue in Europe, and answers biased towards more favorable views are to be expected as the general ethical attitude and rhetoric of public opinion leaders is one of tolerance and inclusiveness. The minaret referendum and the preceding opinion poll that was substantially off the mark prove that point spectacularly. The analysis of actual voting behavior would not suffer from such a bias. Second, proposals on the political agenda targeting at religious minorities would either be unconstitutional as they violate fundamental non-discrimination principles, or they are intertwined with economic motives, which makes disentangling attitudes towards the minorities from economic interests very difficult, if not impossible. For instance, laws restricting immigration would significantly limit the influx of Muslim immigrants in many European countries; at the same time, they would reduce the workforce, especially for low-skilled labor, with obvious consequences for wages and unemployment. ${ }^{3}$

The minaret referendum in Switzerland is a unique case, in which actual voting behavior in a free and secret ballot is observable, a religious minority is explicitly targeted as such and no additional economic motive is present. The bill exclusively prohibits the erection of minarets at mosques in Switzerland. It is the single nation-wide referendum ever in a democratic state that restricted the freedom of religious expression as its single issue and therefore provides a unique opportunity to investigate the determinants of aversion to Islam.

The minaret referendum was held on November 29, 2009. The ballot initiative pro-

\%, 2015), Fidesz in Hungary (44.5 \%, 2014), Prawo i Sprawiedliwosc in Poland (37.6 \%, 2015), and Alternative für Deutschland in Germany $(12.6 \%$, 2017). In Switzerland, the right-wing populist party Schweizerische Volkspartei (SVP) had the largest vote share at $29.4 \%$ in the 2015 elections.

${ }^{3}$ Likewise, the vote share of right-wing populist parties, which often have strong nationalist and antiIslamic stances, is not informative for the degree of Islamophobia as the decision to vote for right-wing parties depends not only on the degree of xenophobia and Islamophobia, but also on other program elements, such as their announced economic policy, the voting system, and the attractiveness of established parties (Kitschelt 1995, Jackman and Volpert 1996). 
posed a constitutional ban on the construction of minarets; it was launched by the rightwing Schweizerische Volkspartei, the single largest party in Switzerland with a vote share of almost $27 \%$ in the 2007 federal election, and the Eidgenössische Demokratische Union (EDU), a fringe party that advocates Christian values. Proponents of the bill argued it would safeguard Switzerland against an insidious ascent of the alien Muslim community, which, if not countered appropriately, would ultimately lead to its dominance and the spread of Sharia law. The Swiss federal government (Bundesrat) warned that the initiative would conflict with the Swiss constitution, especially with the freedom of religious expression, and the two chambers of parliament recommended rejection with large majorities. The Protestant and Catholic Churches as well as all parties except for the SVP and the EDU were opposed to the bill. ${ }^{4}$

While opinion polls prior to the referendum as well as exit polls at the referendum day forecasted its rejection, the bill was adopted with a considerable majority of $57.5 \% .^{5}$ As a consequence, Art 72 of the federal constitution (Bundesverfassung) was amended by a third paragraph, stating 'The construction of minarets is prohibited.' (BBl 2009 4381). ${ }^{6}$

Our study investigates the determinants of voting behavior in the Swiss minaret referendum. It resonates with the literature on the role of income and education on extremist attitudes and voting for extremist parties. This literature is largely inconclusive. Jackman and Volpert (1996) find that electoral support for right-wing parties varies positively with unemployment, Golder (2003) argues that unemployment produces a large vote share for right extremist parties only if coupled with large immigration, and Arzheimer (2009) finds a complex interaction between unemployment, immigration and other factors. In contrast, Knigge (1998) and Lewis-Beck and Mitchell (1993) find no evidence of the impact of economic conditions on the share of votes for extremist parties. ${ }^{7}$ Opinion surveys

\footnotetext{
${ }^{4}$ Allenbach and Sökefeld 2010; Für religiösen Frieden - gegen Minarettverbot, NEUE ZÜRCHER ZEITUNG [NZZ], Sept. 3, 2009, p. 14. Minarett-Initiative: Befürworter legen zu, TAGESANZEIGER, Nov. 19, 2009, p. 4.

${ }^{5}$ An influential opinion survey conducted in mid October predicted $53 \%$ voting against the initiative and $34 \%$ voting in favor (Longchamp et al. 2009). The turnout was $53.9 \%$ (http://www.bfs.admin. ch/bfs/portal/de/index/themen/17/03/blank/key/2009/05.html).

${ }^{6}$ See Langer (2010) for a detailed description of the circumstances leading to the referendum and its legal implications.

${ }^{7}$ Obviously, there are many other determinants for right-wing party support, cf. e.g. Rydgren (2007).
} 
are a second source of information: Dustmann and Preston (2001) show for Britain that individuals with higher education have more favorable attitudes towards foreigners while unemployment status has no effect. Mayda (2006) demonstrates that high-skilled individuals view immigration more favorably. Fertig and Schmidt (2010) corroborate this finding for Germany; the only variable that drives the difference in attitudes towards foreigners and Jews is education. Dustmann and Preston (2007) show, among other things, that British people are more strongly opposed to immigration from countries with an ethnically different population. Lastly, the literature on hate crimes largely fails to find a significant impact of economic conditions on the incidence of these crimes. ${ }^{8}$ In short, the role of income and education on xenophobia, Islamophobia, and political extremism is still an open research question.

Our paper also contributes to the literature on the impact of the presence of foreigners on the attitudes towards foreigners or, in our context, the number of Muslims on the degree of Islamophobia. The 'racial threat' hypothesis developed in the Southern US posits that white voters become more intolerant towards blacks with an increasing presence of blacks (inter alia Key 1949, Giles and Hertz 1994). Empirical evidence has been mixed. Bowler et al. (2006) find supporting evidence for the 'racial threat' hypothesis in California, where a higher presence of Hispanics has led to more conservative voting by whites (see also Kitschelt 1995). Voss (1996) does not find such an effect for the Southern US. French and Austrian regions with higher numbers of immigrants experienced more support for extremist right parties; but this did not apply for Germany (Givens 2002). Dustmann and Preston (2001) argue that sorting will lead to more tolerant people living in neighborhoods with larger minority groups. After correcting for this bias, they show that a higher concentration of ethnic minorities leads to more hostile attitudes. The 'contact hypothesis' maintains that xenophobe attitudes may be reduced if people have more contact with the

\footnotetext{
${ }^{8}$ Jefferson and Pryor (1999) find no correlation between the existence of hatred groups and the unemployment rate or the income gap between whites and blacks in the US. Likewise, hate crimes against ethnic groups or homosexuals were uncorrelated with unemployment in New York between 1987 and 1995 (Green et al. 1998). No correlation exists between unemployment and ethnic violence in reunified Germany, after controlling for former East Germany (Krueger and Pischke 1997). In contrast, Honaker (2008) finds unemployment among Protestants and Catholics to be a leading cause of the violence by the respective factions in Northern Ireland.
} 
respective minority (Allport 1954; Amir 1969). ${ }^{9}$ Stein et al. (2000) show that in more diverse counties whites were opposing immigration more if contact with Hispanics was low, but not if it was high (see also Husband 2002 and Dixon and Rosenbaum 2004 for evidence supporting the 'contact hypothesis'). Glaser (1994) shows that contact with other ethnicities leads to more aversion in situations in which competition and inequality persists. Overall, the evidence is far from conclusive.

Our results show that approval rates for the minaret referendum in Switzerland increase with unemployment and are higher for voting districts with lower educational attainment and lower income. We find evidence for a strong gender gap - districts with a higher share of women show a lower approval rate. There is a strong divide between the different language groups: The German-Swiss districts and especially the Italian-Swiss districts have significantly higher approval rates than the French-Swiss and in particular the Rhaeto-Romanic districts.

The prohibition to erect minarets affects the Muslim minority, which is at the same time almost exclusively foreign or of foreign descent. The minaret referendum thus targets a double minority. Switzerland has a Muslim population of around 400,000, which is approximately five percent of the entire population. ${ }^{10}$ Thus, xenophobic and Islamophobic attitudes may overlap in the motivation to vote for the proposal. In order to shed light on potentially different determinants for Islamophobic and xenophobic motivations, we compare the approval rates in the minaret referendum with those of the naturalization referendum in 2008, which proposed to tighten naturalization procedures for all foreigners alike by making appeals against negative naturalization decisions impossible. The

\footnotetext{
${ }^{9}$ Boisjoly et al. (2006) show that white college students who were randomly assigned to black roommates held more favorable views towards minorities.

${ }^{10}$ There is no exact current figure on Muslims in Switzerland available. In the 2000 census the Federal Statistical Office (Bundesamt für Statistik, BFS) counted around 311,000 Muslims in Switzerland (BFS 2003). The number has been increasing sharply: In 1970, around 16,000 Muslims lived in Switzerland, their number rose to 56,625 in 1980 , to 152,217 in 1990 and to 310,807 in 2000 . In the media, the current Muslim population is estimated at 400,000 (see for example Geringere Zuwanderung von Muslimen, TAGESANZEIGER, November 3, 2009). In 2010, the number of Muslims among all permanent Swiss residents aged 15+ amounted to 295,798 (BFS: http://www.bfs.admin.ch/bfs/portal/de/index/news/ medienmitteilungen.html?pressID=8089). Less than $12 \%$ of the Muslim population are Swiss citizens; most of the Muslim residents come from former Yugoslavia and Turkey, only $5.6 \%$ are of Arab descent (EKM 2010). The immigrant groups are unequally spread over the territory of Switzerland (Allenbach and Sökefeld 2010).
} 
differencing the approval rates of both referenda allows to identify differences between drivers of Islamophobia and xenophobia, as Islamophobic motivations will be relatively more dominant compared to xenophobic motivations in the minaret referendum than in the naturalization referendum as the former targets exclusively Muslims while the latter affects all foreigners.

We proceed as follows: Section 2 describes the minaret referendum. In section 3, we introduce the data, derive testable hypotheses and explain our empirical approach. The estimation results of the minaret referendum analysis are presented in section 4 . Section 5 contains robustness checks; in particular, we address the potential problem of ecological fallacy. Section 6 compares the determinants of Islamophobia to those of xenophobia. Section 7 concludes.

\section{The Minaret Referendum}

The popular initiative against minarets was a response to a number of failed attempts to inhibit the construction of minarets at the local level. The public aversion against Islamic prayer spaces is a relatively new phenomenon in Switzerland. Prior to the minaret conflict that led to the referendum, the construction of an Islamic prayer space had never sparked controversy. ${ }^{11}$ In 2009, there were approximately 400,000 Muslims in Switzerland, corresponding to around $5 \%$ of the total population. In 2009, there were around 200 mosques and prayer spaces in Switzerland, only four of which had a minaret. ${ }^{12}$

The minaret controversy began in 2006 with the resistance against the erection of minarets on existing Muslim prayer spaces in three Swiss municipalities, Wangen bei Olten (canton Solothurn), Langenthal (Bern) and Wil (St. Gallen), and with the planned construction of an Islamic Center in Bern. The planned minaret in Wangen was the first to stir opposition. After the Turkish cultural association requested permission to construct

\footnotetext{
${ }^{11}$ When, at the beginning of the $1960 \mathrm{~s}$, the Mahmud mosque of the Ahmadiyya was built, there was hardly any criticism. Neue Zürcher Zeitung, September 23, 2006, http://www.nzz.ch/2006/09/23/zh/ articleEHTTK.html.

${ }^{12}$ http://www.euronews.net/2009/11/19/minaret-debate-angers-swiss-muslims/, until 2015, the number increased to $240 \mathrm{http}: / /$ www.20min.ch/schweiz/news/story/12178273 accessed June 9, 2017.
} 
a minaret, the community attempted to counteract this by collecting signatures. The Communal Planning Commission rejected the application, but the applicants filed an appeal to the Building and Justice Department, which revoked the initial decision. As a reaction to this, the community of Wangen brought the case before the Administrative Court of the Canton of Solothurn. The claim was refused. The residents of Wangen appealed to the Federal Supreme Court, which concurred with the decision of the lower court. ${ }^{13}$ The minaret in Wangen was erected in January 2009; it is the fourth minaret in Switzerland. ${ }^{14}$ The minaret controversy in the other two municipalities, Langenthal and Wil (St. Gallen), developed similarly to the conflict in Wangen.

As the building applications were filed, the minaret controversy rapidly reached the national politics and the media. The Swiss People's Party had communicated their aversion against minarets early on, and even before turning into a countrywide referendum, there had already been some (unsuccessful) attempts to ban the construction of minarets at the cantonal level. On May 1, 2007, the Swiss People's Party and the Confederate Democratic Union of Switzerland (EDU) launched a popular initiative seeking a constitutional ban of minarets at the federal level. The initiative aimed at the modification of article 72 of the Swiss Federal Constitution, which regulates the relation between church and state, by including the following sentence: "The construction of minarets is prohibited". According to Swiss law, an initiative committee must collect 100,000 signatures within 18 months to move the initiative to the next stage in the legislative process (Stüssi 2008, Langer 2010). On July 8, 2008, the initiative committee (the so called "Egerkingen Committee") submitted 113,540 valid signatures to the Federal Chancellery. ${ }^{15}$ In a report to the Federal Assembly, the Federal government (Bundesrat) established the validity of the minaret initiative, stating that it did not violate peremptory norms of international law, but recommended the rejection of the proposal. The National Assembly accepted the conclusions of the government and also recommended rejecting the ballot (Langer 2010).

\footnotetext{
${ }^{13}$ Federal Tribunal, http://www.bger.ch/mediencommunique_d.pdf.

${ }^{14}$ The first minaret was constructed in Zurich (1963), other minarets were erected in Geneva (1978) and Winterthur (2005). http://www.kath.ch/pdf/kipa_20060714162947.pdf, http://www. inforel. ch/fileadmin/user_upload/dateien/091105_Argumentarium_Minarettinitiative_KIOS_FIDS.pdf.

${ }^{15}$ http://www.admin.ch/opc/de/federal-gazette/2008/6851.pdf; http://www.news.admin.ch/ message/index .html?lang=de\&msg-id=20309.
} 
The Swiss Business Federation as well as leaders of the Catholic and Protestant Churches also recommended to reject the initiative. ${ }^{16}$

In the view of the initiators of the minaret referendum, minarets have a political dimension. They argued that it symbolizes the claim of Islam to religious-political power, while the exercise of religion plays only a minor part. The initiators feared that accepting minarets would ultimately lead to having to accept the muezzin's call to prayer and that the minaret, as an Islamic power-symbol, would express an undemocratic claim to sole representation. They also argued that a mosque does not necessarily have to have a minaret and that the ban would therefore not affect the religious freedom of Muslims. ${ }^{17}$ By contrast, the ban's opponents emphasized that the initiative violates national and international provisions on non-discrimination and the free exercise of religion and would threaten the religious peace in Switzerland. The minaret ban would limit the Muslims in the expression of their faith and would not be compatible with democratic values. ${ }^{18}$

The anti-minaret campaign was conducted aggressively. Initiators used a poster showing a burka-clad woman and minarets as rockets piercing the Swiss national flag. The poster was prohibited in some municipalities and criticized by the Swiss Commission Against Racism as well as by the UN Human Rights Committee. ${ }^{19}$

On November 29, 2009, the referendum was adopted by $57.5 \%$ of the votes; the required cantonal majority was also obtained. Only four of the 26 Swiss cantons rejected the initiative (Geneva, Waadt, Basel-City, and Neuenburg). ${ }^{20}$

The minaret initiative was the subject of heavy criticism by the media, foreign politicians, and international institutions, the main issue being the incompatibility of the minaret ban with the fundamental value of religious freedom. ${ }^{21}$

\footnotetext{
${ }^{16} \mathrm{http}$ ://www. euro-islam.info/key-issues/switzerlands-minaret-ban/\#identifier_1_11285.

${ }^{17}$ The initiative committee:

http://www.minarette.ch/downloads/kurz-argumentarium_minarettverbot.pdf.

${ }^{18}$ The press conference of the Swiss Federal Assembly is available at http://www.tv.admin.ch/de/ archiv?video_id=184.

${ }^{19}$ http://www . euro-islam.info/key-issues/switzerlands-minaret-ban/\#identifier_1_11285. The banner can be seen at http://blog.zeit.de/joerglau/2009/10/09/minarette-verbieten_3114.

${ }^{20}$ http: //www.bfs.admin.ch/bfs/portal/de/index/themen/17/03/blank/key/2009/05.html.

21 The then French Foreign Minister, Bernard Kouchner, described the ban as a "show of intolerance", while the Swedish Foreign Minister, Carl Blindt, called the referendum a "display of prejudice and perhaps even of fear." The Vatican, the UN High Commission for Human Rights, and the Council of Europe Parliamentary Assembly also voiced concern and disappointment about the Swiss vote (http://www. euro-
} 
Many scholars criticized the referendum as well. Stüssi (2008) argues that the minaret initiative is controversial in its nature as a result of a democratic process that violates international law and basic human rights. Langer (2010) states that the minaret ban is incompatible with international obligations of Switzerland, among them the European Convention on Human Rights and the International Covenant on Civil and Political Rights. Kirchgässner (2010a, b) sees an unresolved and, in part, irresolvable conflict at the heart of the problem, taking place between the democratic principle and the rule of law, both fundamental constitutional principles of Western open societies: While democratic decisions have to be respected as the will of the sovereign, they may conflict with basic human rights such as freedom of religion.

While much of the discussion centered on the legal, political and moral fallout of the minaret referendum, little has been said about the determinants of the approval to the initiative. Subsequently, we analyze the characteristics that made people more likely to vote for the minaret ban.

\section{$3 \quad$ Data and Empirical Approach}

\subsection{Main Hypotheses and Data}

We base our hypotheses on evidence from the literature, which was derived in different contexts, such as voting for parties of the extreme right or opinion polls regarding immigration, and investigate whether they carry over to the case of anti-Muslim sentiments in a referendum that has solely anti-Muslim motives and involves no economic issue or policy proposal. We group the determinants into four main categories: economic characteristics of the ballot districts (unemployment, income, educational profile), the share of Muslims in a district ('religious threat' versus 'contact hypothesis'), demographic variables (age, gender) and cultural and political differences between the four language groups in

islam.info/key-issues/switzerlands-minaret-ban/\#identifier_1_11285). Criticism was also expressed by the U.S. Government. At the presentation of the annual Human Rights Report by the U.S. State Department, the Swiss minaret ban was was referred to as the prime example for an increasing trend of discrimination against Muslims in Europe. Criticism was voiced also in Muslim countries and by Muslim organizations (Langer 2010). 
Switzerland, and include additional controls.

There is significant empirical evidence that support for right-wing parties increases with unemployment (Arzheimer 2009, Golder 2003, Jackman and Volpert 1996). Even though others fail to find such relationship (Dustmann and Preston 2001, Lewis-Beck and Mitchell 1993), we test for a possible influence of these economic variables on the decision to vote in favor of the minaret ban. We hypothesize that a possible motive behind the approval of the minaret initiative is not only aversion against a "creeping Islamization" in Switzerland, but that minarets are also seen as symbols for immigration by Muslim foreigners, which is associated with economic disadvantages, especially with rising unemployment. This view is shared, for instance, by the regional party Lega dei Ticinesi in Ticino, which supported the minaret initiative. ${ }^{22}$ People exposed to and threatened by higher unemployment rates, i.e. residents of districts with high unemployment as well as less educated individuals, are hypothesized to be more likely to subscribe to such a view. ${ }^{23}$ Moreover, districts where residents have a higher income are hypothesized to feel less threatened by immigrants, who may reduce the wage level of low-skilled labor. More generally, well-educated and well-off people may be more confident and, as a consequence, less threatened by foreign cultural and religious influences. Indeed, many studies in the European context suggest that individuals with high education have more favorable attitudes towards foreigners (Dustmann and Preston 2001, Fertig and Schmidt 2010, Hjerm 2001). ${ }^{24}$ We summarize this in our first hypothesis.

Hypothesis 1.a. The approval rate rises with unemployment and declines with income in a voting district.

\footnotetext{
${ }^{22}$ FAZ.net of November 30, 2009, Four Minarets and one ban: http://www.faz. net/s/RubFC06D389EE76479E9E76425072B196C3/Doc ECDB332CA4D7245E08F1E87F82DE69.

F9D ATpl Ecommon Scontent.html. Interview with the leader of Lega dei Ticinesi, Giuliano Bignasca available under: http://www.swissinfo.ch/ger/politik_schweiz/wahlen/parlamentswahlen_2007/ parlamentswahlen_2007_hintergrund/Lega_dei_Ticinesi.html?cid=638636.

${ }^{23}$ As Muslim immigrants are predominantly low-skilled, further immigration may increase scarcity rents of human capital, which may provide another reason for high-skilled residents not to support the minaret ban.

${ }^{24}$ Schoon et al. (2010) find that British people with higher cognitive abilities at the age of 11 tend to have socially more liberal attitudes at the age of 33. Rindermann et al. (2012) find for Brasil that more intelligent people tend to have less extremist and more centered political attitudes. Similar evidence is provided by Stankov (2009) for the US and for foreign students entering the US.
} 
Hypothesis 1.b. The approval rate declines with education.

We measure unemployment as annual average in the voting district in percent; income is measured as annual average net income per capita in the district. ${ }^{25}$ The education profile is captured with two variables EDUCATION1 and EDUCATION2, which measure the share of the adult population aged 25-64 years with lower secondary education or below and upper secondary education. ${ }^{26}$ (The share of population with tertiary education is the omitted category.) All variables are described in table A.1 in the appendix.

The 'racial threat' hypothesis posits that a majority may become less tolerant with increasing presence of the minority (Key 1949, Giles and Hertz 1994, Kitschelt 1995 and Bowler et al. 2006). While the hypothesis was developed in the context of racial relations between blacks and whites in the Southern US and evidence has been mixed so far, the logic could be transferred to a possible religious antagonism between Christians and Muslims in the Swiss context. It would imply that districts with a higher Muslim population would exhibit higher approval rates for the bill. We measure the presence of Muslims with the share of Muslims in the municipality in 2000 (MUSLIM2000) or with the share of people in a municipality with Muslim country citizenship (MUSLIM2010). ${ }^{27}$

This hypothesis could be refined as Christians are no monolithic group. The antagonism between Muslims and Christians may be more pronounced if the majority society is not divided itself. If Catholics and Protestants coexist both in large numbers in a district, a third religious group may stir less resentments than if there is only one dominant religious group. We capture this idea with two dummy variables, CATHOLICS and PROTESTANTS, which become one if the respective group has a share in the population above $70 \%$. Alternatively we use the dummy variable RELIGION MIX, which is one if neither Catholics nor Protestants have a share of $70 \%$ or above in a district. ${ }^{28}$

\footnotetext{
${ }^{25}$ We divide the total income in each district by the number of inhabitants.

${ }^{26}$ The lower secondary education category contains also people with missing education information.

${ }^{27}$ The variables are based on the 2000 and 2010 census respectively as no 2008 data are available. Note that the variables for 2000 and 2010 are different: While the variable MUSLIMS 2000 represents the share of Muslims in the population, the data for 2010 contain only information on the nationality. On this basis, we calculate the shares of people with citizenship of an Islamic country for each municipality.

${ }^{28}$ In one specification, we include the variable CREEDLESS, denoting the share of people without religious affiliation. The reason is that one might expect the disagreement to be not predominately between religious groups but between religious and creedless people as Muslims are confronted with similar problems as Christians in a secular society as argued by Helbing (2008).
} 
The alternative 'contact hypothesis' maintains that aversion against a racial minority is reduced if members of the mainstream society have more contact with the respective minority (Stein et al. 2000, Husband 2002, and Dixon and Rosenbaum 2004). This implies that approval rates would be lower in voting districts with a large Muslim population as contact with Muslims is more frequent. Using data from a representative survey in a large Swiss city, Stolz (2005) finds that personal contact with Muslims has no mitigating effect on Islamophobia. We formulate our second hypothesis as:

Hypothesis 2.a. ('religious threat hypothesis') The approval rate rises with the share of Muslims in a district.

Hypothesis 2.b. The approval rate declines if neither Catholics nor Protestants hold a dominating majority in the district.

There is evidence derived in other contexts that the political attitudes of women are significantly different from men's. In particular, women tend to be less xenophobic and support extreme right parties less than men (for instance Gidengil et al. 2005, Pratto et al. 1997, Sichone 2008). ${ }^{29}$ Based on this evidence, we suppose the gender effect to have the same direction in an Islamophobic context and therefore include the share of women in a voting district (WOMEN). We formulate our third hypothesis as

Hypothesis 3.a. The approval rate declines with a rising share of women in a district.

People may feel more threatened by the foreign, the more vulnerable they feel. Individuals with children may feel more vulnerable and thus oppose Islamic influences more. In contrast, young adults may feel less threatened by Islamic influences. Studies have found that in general, older people tend to be more xenophobic than younger individuals (Gorodzeisky and Semyonov 2009, Quillian 1995). ${ }^{30}$

We hypothesize that this holds also in the context of Islamophobia:

\footnotetext{
29 There are marked gender differences in voting behavior in Europe. They follow a similar trend as in the US - while women tended to vote more for conservative parties in the 1970s, they have given higher support to the left parties in the last decades (Giger 2009).

${ }^{30}$ We note that young, uneducated men are by far overrepresented among the supporters of parties of the extreme right (Lubbers et al. 2002, Kessler and Freeman 2005). This does not imply, however, that young individuals are predominantly supporters of right extremist parties as this group is only a minority in society.
} 
Hypothesis 3.b. The approval rate increases with a rising share of people below 20 years of age. It decreases with a rising share of people between 20 and 39 years.

To investigate the effect of the age structure, we include the share of people aged 0-19, 20-39, and 40-59 years (AGE 0-19, AGE 20-39, AGE 40-59) with the share of people aged 60 or older being the omitted reference category.

Switzerland is divided in four different language groups, which are at the same time culturally and politically quite different: the German speaking group and the three LatinSwiss groups speaking French, Italian, and Rhaeto-Romanic (Büchi 2003). ${ }^{31}$ There is evidence of significant differences in voting behavior between the different Swiss language groups. The German-Swiss language group has been consistently more conservative than the Latin-Swiss groups (Hermann and Leuthold 2003). Danaci (2009) argues that in the French-speaking part of Switzerland two countervailing effects influence the opinion on the naturalization of Muslims: While Romands are in general less restrictive on naturalization issues than Swiss-Germans, they are more restrictive on the display of religious symbols in public like wearing headscarves. The study argues that both effects can be explained by the Romands' cultural closeness to France, where the aversion for religious symbols is related to secularism of France, i.e. the strict separation of church and state. A priori, it is not clear which effect will dominate. For the Italian-speaking Swiss, we expect high approval rates for the minaret ban because of their restrictive voting behavior in referenda on foreign affairs. For example, since 1992, this part of Switzerland rejected all initiatives and bills relating to the EU with no-votes between $57 \%$ and $64 \%$, regardless of whether it was about politics or the economy. ${ }^{32}$ We thus formulate

Hypothesis 4. The approval rate varies significantly between the four language groups. German-Swiss and Italian-Swiss municipalities show higher approval rates than FrenchSwiss municipalities.

\footnotetext{
${ }^{31}$ This has been coined the "Röstigraben" phenomenon after the national Swiss-German potato dish ("Rösti"), which is not particularly popular beyond the Swiss-German region; it describes the dividing line in mentality between the two largest language groups in Switzerland - Swiss-German speaking area and French-speaking Romands.

${ }^{32} \mathrm{http}$ ://www.zoonpoliticon.ch/blog/Kategorien/serien/va-personenfreizugigkeit-2009/ page/3/.
} 
We use dummy variables that indicate whether a municipality belongs to a given language group (GERMAN, ITALIAN, RHAETO-ROMANIC) and use French-Swiss as reference group.

We include a number of additional control variables. The variables RURAL and PERIPHERY indicate whether a municipality belongs to a rural area or to the periphery of an urban agglomeration as peripheral and rural areas have been shown to have more conservative attitudes in referenda and less welcoming attitudes towards foreigners. We control for the sector composition of municipalities' economies by including the variable TERTIARY, i.e. the share of employees in the tertiary sector. Attractiveness of a location is captured by CRIME indicating the overall crime level (criminal acts per 1000 residents) and by the MIGRATION BALANCE, the net inflow of population into a municipality.

\subsection{Data Sources}

This study links referendum data to a wide range of economic and socio-demographic data at the municipality level. The municipalities are identical with the ballot districts. We use three data sources: the State Secretariat for Economic Affairs for unemployment data, the Swiss Federal Tax Administration (ESTV) for income data and the Swiss Federal Statistical Office (BFS) for all remaining data.

Most variables refer to 2008, the year before the minaret referendum, yet some variables relate to other points in time close to this year. ${ }^{33}$ Where current data do not exist, census data from 2000 were used. Because the used census data refer to relatively time-constant characteristics like language dominance in the municipalities, religion, and assignment of municipalities to urban or rural areas, this should not be problematic for the analysis. Only with regard to the information on Muslim population, census data might not be quite reliable due to a possible change in the regional structure of these characteristics over time. For this reason, we construct an alternative variable to capture the size of Muslim population using more current information on the composition of municipal population by nationality. We approximate the population of Muslims by the

\footnotetext{
${ }^{33}$ This applies for income (2006), share of SVP votes (2007), and crime and unemployment rates (both 2009).
} 
share of people with citizenship of an Islamic country. ${ }^{34}$ Since information on nationality as well as on age structure in Swiss municipalities is not available for the referendum year or the periods shortly before, we use data from 2010 for these characteristics. The age and nationality data have more current municipality structure and contain fewer municipalities than in the referendum year. Hence, there are fewer observations in specifications using these variables. Because of this, the variables age and Muslims 2010 are omitted in some specifications.

To account for a changing municipality structure over time, all data referring to a different time period (especially census data) were transformed accordingly to the municipality structure of the referendum year. Between the census year (2000) and the referendum year (2009), there were approx. 130 fusions of municipalities. We calculated weighted averages for merged municipalities using the number of inhabitants as weights for most of the variables. If another base population was taken for the construction of variables (i.e. calculation of the proportions), we used the appropriate weights. For instance we weighted the economic sectors with the number of the employees and the educational variables with the number of inhabitants aged 25-64. In total, approx. $6 \%$ of the data were derived through these procedures. As a robustness check, we excluded the municipalities that had merged. The results were largely unaffected by this. Our sample consists of 2,612 Swiss municipalities. ${ }^{35}$ The data description and descriptive statistics are given in the appendix, table A.1.

\subsection{Empirical Approach}

We use the approach that has become standard for the analysis of referenda (McFadden 1973). An individual votes in favor of a bill if his or her utility is larger if the bill is adopted than if it is rejected. The utility of the voter in these two states depends in turn on a vector of observable characteristics $X_{i}$, such as age, gender, and education and on unobservable traits. In our context, unobservable determinants could include the degree of self-confidence, individual experiences, especially with Muslim foreigners, whether the

\footnotetext{
${ }^{34} \mathrm{~A}$ country is defined as Islamic if the share of Muslims is at least $50 \%$.

${ }^{35}$ This corresponds to the number of municipalities in the referendum data (without external voting).
} 
individual was brought up in a tolerant home etc. Since we cannot observe these factors, we relate the probability $P_{i}$ that an individual $i$ will vote "yes" in a referendum to the vector of observable socio-economic variables $X_{i}$ only and assume that the utility derived from these unobservable factors is distributed in some way. We use a logit representation which assumes that the probability of voting "yes" can be described by a cumulative logistic probability function of these exogenous variables $X_{i}:{ }^{36}$

$$
P_{i}=F\left(\alpha+\beta X_{i}\right)=\frac{1}{1+e^{-\left(\alpha+\beta X_{i}\right)}}
$$

Rearranging and taking natural logarithms yields

$$
\log \frac{P_{i}}{1-P_{i}}=\alpha+\beta X_{i}
$$

Due to the secrecy of the ballot, we do not have individual data but only grouped data for each ballot district. If we assume identical individuals with respect to $X_{i}$, we can approximate the probability $P_{i}$ that a representative voter will vote "yes" by the fraction of voters that actually voted "yes", i.e. $\tilde{P}_{i}=\frac{y_{i}}{v_{i}}$ with $y_{i}$ denoting the number of voters in ballot district $i$ who actually voted "yes" and $v_{i}$ denoting the number of voters participating in the referendum in this ballot district. ${ }^{37}$ Thus, we replace $P_{i}$ by $\tilde{P}_{i}$ to arrive at the regression equation

$$
\log \frac{\frac{y_{i}}{v_{i}}}{1-\frac{y_{i}}{v_{i}}}=\tilde{\alpha}+\tilde{\beta} X_{i}+u_{i}
$$

For independent observations (binomially distributed), it can be shown ${ }^{38}$ that the error term in (3) is asymptotically normally distributed with zero mean and variance

$$
\operatorname{Var}\left(u_{i}\right)=\frac{\frac{v_{i}}{y_{i}}}{v_{i}-y_{i}}=\frac{1}{v_{i} \tilde{P}_{i}\left(1-\tilde{P}_{i}\right)}
$$

To solve the heteroscedasticity problem, the econometric literature recommends the

\footnotetext{
${ }^{36}$ This section follows the exposition of the logit model by Pindyck and Rubinfeld (1991, ch. 10).

${ }^{37}$ This approximation is sensible because $y_{i}$ is binomially distributed with frequency $\frac{y_{i}}{v_{i}}$.

${ }^{38}$ See Amemiya (1985, pp. 275-277) or Maddala (1983, pp. 28-30) for a derivation.
} 
use of the weighted least squares method. ${ }^{39}$ In the process, the standard errors are used for weighting, i.e. equation (3) is divided by $\sqrt{\operatorname{Var}\left(u_{i}\right)}$ in order to make the regression homoscedastic. In relation to the probability $\tilde{P}_{i}$, there are two alternatives for the calculation of weights. First, one can simply use the empirical probabilities $\tilde{P}_{i}=\frac{y_{i}}{v_{i}}$ to compute the weights. This simple version is quite often used in the literature. The second alternative is to use the fitted probabilities for the calculation of weights according to the so-called minimum chi-square logit method. In this method, a two-step procedure is applied. In the first step, the fitted probabilities are estimated by regression of the empirical probability on the set of exogenous variables. The estimated fitted probabilities are subsequently used for the calculation of weights. In the second step, the weights based on the first step estimates can be used for weighted least squares (WLS). This estimator has the same asymptotic properties as the maximum likelihood estimator. ${ }^{40}$ We use both versions of weighting and estimate the second variant (weighting with fitted probabilities) as a robustness check for the results (appendix, table A.2).

Alternatively to linear models using empirical probabilities $\tilde{P}_{i}$ or corresponded logodds ratio as the dependent variable, Papke and Wooldridge (1996) specify a class of functional forms and propose a robust quasi-likelihood estimation method. ${ }^{41}$ Papke and Wooldridge (1996) point out potential problems associated with the model described by the equation 3 . The equation 3 cannot be estimated if any of the proportions $\frac{y_{i}}{v_{i}}$ are equal to zero or one. For those values the $\log$-odds ratio $\log \frac{\frac{y_{i}}{v_{i}}}{1-\frac{y_{i}}{v_{i}}}$ is not defined and the model cannot be applied without additional adjustments. ${ }^{42}$ For the case that $\frac{y_{i}}{v_{i}}$ are fractions from a fixed number of groups with known group size, Papke and Wooldridge (1996) refer to the minimum chi-square method described for example in Maddala (1983, p. 30, see above). However, for some cases the minimum chi-square method is not applicable,

\footnotetext{
${ }^{39}$ Another possibility is to use heteroscedasticity-consistent standard errors within a simple ordinary least squares (OLS) estimation. However, since OLS is not fully efficient, weighted least squares may achieve efficiency gains (Cameron and Trivedi 2005, p. 84).

${ }^{40}$ See Green (2002), pp. 688-689, Amemiya (1985), pp. 275-280, and Maddala (1983), pp. 28-30.

${ }^{41}$ Papke and Wooldridge (1996) propose a quasi-likelihood method based on the Bernoulli log-likelihood function $l_{i}(b) \equiv y_{i} \log \left[G\left(x_{i} b\right)\right]+\left(1-y_{i}\right) \log \left[1-G\left(x_{i} b\right)\right]$, where $G(\cdot)$ is a function satisfying $0<G(\cdot)<1$, for example logit or probit.

${ }^{42}$ One possibility, which is widely used is to add or subtract a small value, for example 0.001 , to or from the given proportion if it is zero or one (see Green 2002).
} 
for example, if the term $\frac{y_{i}}{v_{i}}$ is not a proportion from a discrete group size. ${ }^{43}$ Moreover, adjusting the extreme values is not a suitable strategy if a large part of the data is at the extreme values of zero and one. The fractional logit regression provided by Papke and Wooldridge (1996) is very well suited especially for handling fractional response data in which $P_{i}$ takes on the values zero or one with positive probability. Since this problem is not present in our data $\left(\frac{y_{i}}{v_{i}}\right.$ never assumes a value equal to zero or one), we use this approach only as a sensitivity analysis (see appendix, table A.2). ${ }^{44}$

We relate the average voting behavior, i.e. the approval rate, to the average socioeconomic characteristics in the districts. McFadden and Reid (1975) show that for heterogeneous groups the use of averages may lead to an underestimation of individual elasticities. There is no way of avoiding this problem without the knowledge of the covariance matrix of $X$ for each group. Because such data is not available, our results focus on the average behavior of the group and constitute a lower limit for individual behavior.

\section{Results}

Our results are summarized in table 1 . The dependent variable is the approval rate in all models (cf. section 3.3). The analysis shows that economic factors play a significant role in explaining the extent of Islamophobia. The approval rate increases ceteris paribus with higher unemployment rate; the estimated coefficient is highly significant and sizable. This may suggest that in areas with higher unemployment citizens tend to make foreigners or Muslims responsible for the lack of jobs or high unemployment.

- Table 1 here -

The effect of per capita income on the approval rate is negative, sizeable, and highly significant - richer people are less likely to support the minaret ban. Education has a strongly negative effect on approval rates: Districts with higher shares of people with tertiary education exhibit significantly lower approval rates. There are no significant

\footnotetext{
${ }^{43}$ It should be also noted that the weighted estimation may be inappropriate if the model is misspecified.

${ }^{44}$ We implement the fractional logit regression with Stata as shown in Baum (2008), p. 302.
} 
differences between the effect of lower or upper secondary education shares for the voting behavior ( $\mathrm{t}$-value $=-1.59$ ). The estimated effects of education are comparable across all estimation methods. Our results are in line with studies of Dustmann and Preston (2009) and Fertig and Schmidt (2010) and corroborate Hypotheses 1a and 1b.

In order to test the contact hypothesis against the religious threat hypothesis, we included the variable shares of Muslims. We use two alternative variables for the size of the Muslim population: The first variable contains direct information on the share of Muslims from the 2000 census (MUSLIMS 2000), while the second variable denotes the share of foreigners from Islamic countries using nationality data for the year 2010 (MUSLIMS 2010). Both variables have positive, statistically significant effects (at the $5 \%$-level) of similar magnitude; the effect of Muslim share is slightly higher when we use more current data. Our results strongly support the 'religious threat' hypothesis (Hypothesis 2a): the higher the proportion of Muslims in a region, the higher the share of people that seek to ban symbols of Islam. ${ }^{45}$

The religious profile of municipalities has an effect on voting behavior beyond the share of Muslims. Approval rates are significantly higher if Catholics or Protestants have a dominating share in the population (see specification (3) in table 1). Although the effect is higher for Protestants than for Catholics, the difference is not significant (t-value $=0.62$ ). Approval rates decline with the share of creedless people and are lower for municipalities with a mix of different denominations. Our findings support Hypothesis $2 \mathrm{~b}$; they suggest that more homogeneous societies are less tolerant to foreign religions than societies with mixed religious profiles, which already learned how to coexist with one another.

We find evidence for a strong gender effect in approval rates. Municipalities with larger shares of women show a significantly lower support for the initiative. This effect is robust in all models. ${ }^{46}$ This corroborates evidence found in other contexts (Gidengil et

\footnotetext{
${ }^{45}$ In one specification we included the share of foreigners and the share of votes for the populist antiIslam SVP in addition to the share of Muslims. In this specification the share of Muslims is no longer significant, but this is because the vote share of the SVP is significantly larger in districts with a higher share of Muslim population, cf. table A.3 in the appendix.

${ }^{46}$ The effect could be explained by different attitudes of women compared to men, but also - at least in principle - by men behaving differently if the share of women is larger. Since we have only grouped
} 
al. 2005, Pratto et al. 1997, Sichone 2008) and supports Hypothesis 3a.

The results on the influence of the age structure on voting behavior show that the approval rate increases significantly with increasing population shares in the age groups 0-19 and 40-59, while the middle age group has a negative effect on the approval rate (compared to the reference category of people aged 60 and above). This supports the notion that individuals with children are more likely to oppose symbols of Islam as they might feel more threatened by these alien influences. Hypothesis $3 \mathrm{~b}$ is corroborated.

We find highly significant and very strong differences in voting behavior between the four language groups in Switzerland. Swiss-Germans are much more likely to support the Minaret ban than the Romands (the reference group), but the Italian-speaking part of Switzerland is even more opposed to the erection of minarets. Only the small group of Rhaeto-Romanic seems to have a more liberal attitude than the Swiss-Romands. These results are in line with the more liberal, less conservative attitude of Swiss-Romands compared to Swiss-Germans (the so called 'Röstigraben' (Rösti ditch) phenomenon). The French-speaking part may have supported more strongly the separation of church and state following the French tradition, however, this did not translate into higher approval rates for the minaret referendum.

The restrictive voting behavior of the Italian speaking part of Switzerland can be explained by its cultural closeness to Italy, in which strong xenophobic attitudes prevail. Leading representatives of the Italian People of Freedom party (Il Popolo della Libertà, PdL), the party of the former Prime Minister Silvio Berlusconi, officially supported the anti-minaret initiative. Similarly, the (North) Italian xenophobic party Lega Nord received the referendum results with big enthusiasm. ${ }^{47}$ Hypothesis 4 is corroborated - very obviously not only economic, but also cultural factors shape the attitude towards Islam in Switzerland (and possibly elsewhere).

\footnotetext{
data we cannot disentangle these two channels explaining the gender effect.

47 "Now over the today already almost islamicized Europe flutters the flag of courageous Switzerland which wants to remain Christian", said Euro-MP of the Lega Nord Mario Borghezio. His colleague Matteo Salvini also required such a referendum in Italy and praised Switzerland for the big lesson in democracy and common sense. See Welt-online from November 30, 2009, Cheering and horror about Swiss minaret ban, http://www.welt.de/politik/deutschland/article5376855/Jubel-undEntsetzen-ueber-Schweizer-Minarettverbot.html.
} 
We control for a number of other intervening factors. Our results show that there are sizable differences in voting behavior between urban and rural areas. We use the areal classification of BFS and compare three categories: agglomeration cores (reference category), agglomeration peripheries, and rural areas. ${ }^{48}$ Our results show a clear urban-rural divide: Agglomeration areas support the initiative much less than the agglomeration periphery, which in turn has lower approval rates than rural areas in all but one specification.

To control for other living conditions in the municipalities, we use crime rate as an explanatory variable in the analysis. The effect of crime is negative and highly significant, however, our analysis does not allow for a clear interpretation of this result. It may be the case that in regions with high crime rates, the population has more pressing concerns than that of opposing different religions. It may also be that more tolerant people selfselect into areas with higher crime rates (for instance due to lower rents or because of an "alternative" atmosphere). We include the balance of migration in the regression as an indicator for the attractiveness of the particular municipality. ${ }^{49}$ The results show that the approval rate diminishes ceteris paribus with increasing migration balance, suggesting that in more attractive municipalities, citizens are more tolerant as they have fewer reasons to blame Muslim foreigners.

In order to control for a possible impact of the industry structure on the Islamophobic attitudes, we include the share of employees in the tertiary sector. We find that the minaret initiative found less support in regions with high proportion of employees in the tertiary sector compared to regions with higher shares of employees in the primary and secondary sector.

Additionally, we control for the party landscape and for voter turnout by including the vote share of the populist party SVP in the last parliamentary election before the

\footnotetext{
${ }^{48}$ Rural areas are defined as regions that do not belong to an agglomeration. Agglomerations are urban areas with at least 20,000 inhabitants. The agglomerations consist of a central city (agglomeration core) and other municipalities in the vicinity of the core that have an urban character (agglomeration periphery). In our analysis, we includes also five isolated towns in the category agglomeration periphery (Lyss, Langenthal, Einsiedeln, Davos, and Martigny), as they are structurally similar to the towns in the agglomeration periphery and too few to form a separate category. The BFS definitions are taken from Schweizerische Studiengesellschaft für Raumordnung und Regionalpolitik (2006), http://www.rorep. $\mathrm{ch} / \mathrm{pdf} /$ ROREP_LandlicheRaume.pdf.

${ }^{49}$ This concept refers to balance of internal migration, regardless of the nationality of the migrant and signifies the attractiveness of a location.
} 
minaret referendum (2007) and the voter turnout in the minaret referendum. The results for these variables can only be illustrative because of the obvious endogeneity problem. As the SVP sponsored the referendum the determinants for voting for the referendum and for the party are likely to be correlated. Although the decision to support the SVP may be based in large parts on nationalist and anti-Islamic stances in their programs, other program elements may also have major importance for voters. Therefore, it is interesting to see which of the determinants exert an influence for the minaret referendum once we control for the support of this right-wing party. We find that the approval rate increases significantly with the share of SVP votes in the municipality, as expected, but that the determinants for the voting behavior in the referendum remain significant and of the same sign when including the SVP vote share. Their point estimates are reduced in absolute value, as one would expect, and since the SVP is more deeply rooted in the German-speaking part of Switzerland the estimates for the language groups are altered accordingly, e.g. the effect of the Italian-speaking regions increases in size. ${ }^{50}$ Hence, the referendum does not simply portray support for the populist right-wing SVP, but for this specific issue. The turnout also has a positive significant effect on the approval rate, which demonstrates a mobilization effect which favors the initiators of the referendum.

\section{$5 \quad$ Ecological Inference and Other Robustness Checks}

\subsection{Ecological Fallacy Problem}

Using aggregate data to infer individual voting behavior entails a potential problem of ecological fallacy $(\mathrm{EF})$. The relationships at the aggregate level do not always reflect individual-level correlations; in an extreme case the correlations of these two levels could even have different signs (Robinson 1950).

In our analysis the EF problem can occur as the data we use refer to the population of the municipality and not to the voting population. For example, the share of women

\footnotetext{
${ }^{50}$ We study the determinants of SVP support in the general elections in the appendix, table A.3. It becomes obvious that the voting behavior in the referendum is quite different from the support of the $\mathrm{SVP}$ in the general elections.
} 
in a given municipality $\left(X_{i}\right)$ is known, however, it is not clear how close it is to the corresponding proportion in the voting population $\left(\beta_{i}^{w}\right)$. If these two magnitudes differed substantially because women voter turnout was significantly different from that of men, the use of women population share (instead of women vote share) to explain actual vote outcome would lead to wrong conclusions. The EF problem is formally illustrated in the following table: ${ }^{51}$

\begin{tabular}{l|cc|c} 
& vote & no vote & \\
\hline women & $\beta_{i}^{w}$ & $1-\beta_{i}^{w}$ & $X_{i}$ \\
men & $\beta_{i}^{m}$ & $1-\beta_{i}^{m}$ & $1-X_{i}$ \\
\hline & $T_{i}$ & $1-T_{i}$ &
\end{tabular}

If individual data are available, each individual can be assigned to one of the internal cells in this table. In contrast, aggregated data only contain information about the table borders. In our example, we only know the proportions of women and men $\left(X_{i}, 1-X_{i}\right)$ as well as the turnout $\left(T_{i}\right)$ in each voting precinct, but not the turnout of women and men $\left(\beta_{i}^{w}, \beta_{i}^{m}\right)$.

Generally, individual relations cannot be described with aggregated data alone. To approach this issue, more appropriate data or simplifying assumptions are needed. Due to the secrecy of the ballot, individual data are unobtainable. For that reason, various methods have been developed to tackle the problem of ecological fallacy in the voting research and to quantify the unknown parameters. The earlier approaches are the method of bounds (Duncan and Davis 1953) and the ecological regression (Goodman 1953). The method of bounds merely determines the minimal and maximal values of the valid bandwidth for the unknown parameters. The ecological regression of Goodman estimates the quantities of interest in a regression model assuming that they are constant across ecological units. A more recent approach is the ecological inference (EI) by King (1997), which combines and extends the models used in these earlier works (King et al. 2004). ${ }^{52}$ By

\footnotetext{
${ }^{51}$ Our presentation of the EF problem is based on King (1997) and Gschwend (2006).

${ }^{52}$ King's method combines the principle of the ecological regression with the method of bounds. As a first step, the bounds are calculated; then, the betas are estimated by a random-effect model within the bounds. More specifically, the first stage estimates the parameters of the truncated binomial distribution $(\mathrm{TBN})$ - mean values, variances, and covariance - by maximum likelihood. In the second step, the
} 
combining the principle of the ecological regression with the method of bounds available information is used more effectively (Gschwend 2006).

Despite some concerns (Cho and Gaines 2004, Gschwend 2006), EI is widely used in empirical political science research on voting patterns. In recent years, EI research has proliferated, but some comparative studies show that the modern approaches do not seem to have a clear advantage over earlier methods (see Freedman et al. 1998 [1], Leemann and Leimgruber 2009). ${ }^{53}$ The approach by King (1997) is the most widely used one both in academic research and in practice. ${ }^{54}$ We adopt King's (1997) approach to examine whether ecological fallacy affects our results.

\subsection{Using EI Estimation in the Minaret Referendum Analysis}

Fortunately, ecological fallacy does not affect all variables in our analysis equally. Regarding the EF problem, precinct characteristics can be separated into two categories. The first group consists of variables representing individual characteristics of voters, such as gender, education, and age. By contrast, the variables of the second group do not directly relate to voters as individuals but to the municipality as a whole. Such characteristics can affect the voting behavior in an indirect way, as a result of how the voters perceive their environment. Characteristics representing the municipality atmosphere, such as crime, migration balance, or share of foreigners and Muslims, belong to the second group of variables. Since foreigners do not have voting rights - the same is true for Muslims without Swiss citizenship - these characteristics affect the voting behavior only indirectly, i.e. not as attributes of voters. We argue that the use of aggregated data is suitable for variables of the second group because the precinct atmosphere affects all voters in a similar way.

parameters of interest $\left(\beta^{w}, \beta^{m}\right)$ are identified by a Bayesian simulation on the basis of the TBN distribution estimated in the previous step (King 1997). The basic EI-model has the following assumptions. (1) Unimodality: The parameters $\left(\beta_{i}^{w}, \beta_{i}^{m}\right)$ are truncated bivariate normal. This assumption implies similarity across the areas. (2) There is no spatial autocorrelation between ecological units. (3) There is no aggregation bias.

${ }^{53}$ For the methodological debate see for example Freedman et al. 1998[2], King 1999, and Cho and Gaines 2004.

${ }^{54}$ The method of King was applied for example by Burden and Kimball 1998, and Liu 2001 and was used in most US American states for redistricting after the 2000 Census (King et al. 2004). Since the late 1990s, King's EI solution (1997) has been the benchmark method the US courts use to evaluate racial voting patterns in American elections and it has been widely applied in comparative politics research on group and ethnic voting behavior (Collingwood et al. 2016). 
Therefore, ecological inference is only needed for variables of the first category. Since the variables of the second group dominate in our data, the EF is not expected to be a major issue in our study.

For the variables of the first group (share of women, education, unemployment, age, and employment in tertiary sector) we estimate the unknown parameters using the EI method of King and include these estimates as additional variables into our main specification. We apply the weighted least squares method as described in section 3.3. Note that ecological inference can be applied only for proportion variables, i.e. the share of people in a precinct with a particular characteristic (Collingwood et al. 2016). Therefore, we cannot estimate ecological inference for the income variable as well as for the dummy variables, such as language groups, peripheral and rural areas, and religious affiliation. ${ }^{55}$

Table 2 reports the results estimated with and without ecological inference. In the EI model 1 only the share of women is estimated by EI. The second EI model presented in table 2 includes all possible EI variables (share of women, education, unemployment, age, and employment in tertiary sector).

- Table 2 here -

As shown in table 2, the results of the specifications with and without the variables estimated by the ecological inference are very similar. The effects point in the same direction and are in line with our main results. The coefficients of the gender and education variables are slightly decreasing, while the effect of unemployment becomes stronger. However, some age categories, one each in the models 1 and 2 become insignificant. ${ }^{56}$ The estimates for the variables, which were not modified by the EI procedure, are also very similar to our main specification. Only the coefficients of the income variable and the share of Muslims increase in absolute values, the effect of the Rhaeto-Romanic area becomes insignificant. Our main results are thus corroborated when using ecological inference.

\footnotetext{
${ }^{55}$ We carried out a graphical EI analysis exemplarily for the gender variable, which is available upon request.

${ }^{56}$ We have also examined religious characteristics (share of people without religious affiliation) using EI estimation. The coefficients of the original variable and by the EI estimated variable are almost identical. Since this variable has not been used in our main specification, these results are not shown here.
} 


\subsection{Further Robustness Checks}

We carried out additional robustness checks. First, to analyze whether the changes in the municipality structure may have affected the results, we estimated the same specifications as presented in table 1 excluding the merged municipalities. The estimation results for the restricted sample are reported in table A.4 in the appendix. They are very similar.

Second, we examined whether the results are robust to using other estimation methods. Table A.2 reports the results of two alternative approaches, the minimum chi-square logit method and the fractional logit regression, which may be preferable if vote shares are close to zero or one (see Section 3.3). Empirically this is not an issue for our data set, but we still report results from alternative specifications to analyze whether our results depend on the choice of a specific estimation method. Column (1) shows the results using the minimum chi-square logit method. Again, there are no significant deviations from our main results. Column (2) presents the estimates of the fractional logit regression. Most results are confirmed also by this method, especially our central result that a larger presence of Muslims is associated with higher approval rates for the referendum remains significant (at the $10 \%$-level). Yet, some economic factors are not longer significant (unemployment, income, and crime) and the Rhaeto-Romanic language group is no longer different from the French language group. Overall, our results are quite robust to the use of alternative estimation approaches.

\section{Islamophobia versus Xenophobia}

\subsection{Conceptual Issues}

The rhetoric supporting the minaret referendum was clearly anti-Islam and the referendum itself targeted exclusively a symbol of Islam. Therefore, the determinants of the voting behavior in the referendum should reflect the factors that shape Islamophobic attitudes. Yet, Muslims in Switzerland are almost exclusively foreign or of foreign decent. We thus cannot exclude the possibility that xenophobic attitudes superimpose Islamophobic attitudes as the group targeted by the referendum - Muslims - are a special group of 
foreigners.

Moreover, there is no consensus in the literature as to whether xenophobia, describing the general hostility towards foreigners, is a concept different from Islamophobia, the hostility towards Muslims, or whether Islamophobia is but a materialization of xenophobia. Kühnel and Leibhold (2007) and Stolz (2006) argue that xenophobia puts on a different complexion each time depending on the composition of foreigners in a country, which would imply that xenophobic people of today are mainly Islamophobic. In contrast, Helbling (2008) argues that even if the same people have negative attitudes towards foreigners in general and, specifically, towards Muslims, this does not automatically imply that Islamophobia and xenophobia are the same concepts and that they are driven by the same factors. He considers the role of national identity, religiosity, and postmaterial values as possible factors of influence and finds, for example, that religious people who attend church regularly are more xenophobic but less Islamophobic than other people. Religiosity could thus be associated with greater hostility towards foreigners in general but a more understanding attitude towards other religions. Xenophobia would have different determinants than Islamophobia. All of the studies mentioned above use survey data, which entail the distinct possibility of answering biases as the example of the opinion polls preceding the minaret referendum have impressively shown (cf. Section 1, fn. 5).

We seek to shed light on this issue. While we cannot empirically disentangle xenophobic and Islamophobic determinants in the minaret referendum, we can analyze to what extent Islamophobic and xenophobic attitudes have different determinants by comparing voting behavior in the minaret referendum with voting behavior in a referendum that targets all foreigners alike. As Muslims constitute only a quarter of all foreigners in Switzerland, Islamophobic attitudes will carry a larger relative weight in the minaret referendum that targets exclusively an Islamic religious symbol compared to a referendum that affects all foreigners. If determinants differ significantly, it can be traced back to the different relative importance of these two motivations, provided the referenda are otherwise comparable. We provide a short overview of referenda catering to xenophobic attitudes, derive criteria for comparability of referenda, and present the results of such a 
comparison.

\subsection{Referenda Targeting Foreigners in Switzerland}

Xenophobia is no new phenomenon in Switzerland. ${ }^{57}$ Depending on the time period, different groups of foreigners were particularly targeted by xenophobic attitudes. In the second part of 19th century, Jews were the focus of hostile attitudes while today immigrants from Muslim countries are specifically targeted. Yet, there are a number of referenda targeting foreigners as such.

The first referendum against foreigners took place in 1893. The so called "kosher butchering ban" initiative prohibited the slaughtering of animals without prior anesthesia, a religious practice exercised by Jews and Muslims. It was adopted with $60.1 \%$ of the votes. Although the popular initiative was launched by Society for the Prevention of Cruelty to Animals, the adoption of the initiative can be clearly ascribed to the influence of Antisemitism at that time. Interestingly, the differences between the language groups were even more marked than in the recent past - while approval rates for the initiative were larger than $80 \%$ in the German-speaking part, the initiative was clearly rejected in the French and Italian speaking parts. ${ }^{58}$

Since the "kosher butchering ban", over 30 popular initiatives concerning foreigners have been launched. At the beginning of 20th century, a debate on "foreign infiltration" gained momentum. In 1920, the first general xenophobic referendum was initiated. In contrast to the "kosher butchering ban", this initiative addressed foreigners directly and aimed at making the naturalization law more restrictive by conditioning naturalization on cultural assimilation. Another part of the initiative required the federal government to deport foreigners who were posing a threat to the security or welfare of the Swiss people. In the 1930s and 1940s, the foreign infiltration debate played an important role in the Swiss refugee policy: hostile attitudes particularly affected Jewish refugees, who, as a double minority, were affected both by xenophobia and Antisemitism. In the 1960s, the foreign

\footnotetext{
${ }^{57}$ This section is based on information from Swiss Historical Lexicon. Data on referenda are from the BFS, which publishes the voting results of all referenda since the second half of the 19th century.

${ }^{58}$ The share of yes votes stood at $3.1 \%$ in Wallis, $12.8 \%$ in Geneva, and $12.2 \%$ in Ticino as compared to for instance Aargau at $90.1 \%$, Zurich at $85.9 \%$, and Schaffhausen at $84.4 \%$.
} 
infiltration debate experienced a renaissance. This time, the resentment was directed against the working immigrants from Italy. It was argued that Switzerland could lose its national identity due to perceived large influx of foreigners. This debate culminated in a series of four "foreign infiltration" initiatives, which were held within one decade. All four foreign infiltration initiatives were rejected. ${ }^{59}$

In the 1980s, the xenophobic attitudes primarily targeted asylum seekers. In a 1987 referendum, adopted with a $67.3 \%$ majority, asylum regulations were made more restrictive. In 1988, the popular initiative "For the limitation of immigration" was rejected (32.7\% yeas). In the 1990 s and the 2000 s, xenophobia affected not only asylum seekers, but also immigrants especially from non-European countries and refugees from former Yugoslavia. Recently, a number of referenda on immigration issues were initiated, not all of them xenophobic. Most of these affected specific groups of immigrants, such as asylum seekers or second and third generations of immigrants (2002: popular initiative against abuse of asylum right (49.9\% yeas); 2004: Federal decision on the facilitated naturalization of young foreigners of second generation (43.2 \% yeas); 2004: Federal decision on the citizenship rights of third generation of foreigners (49.8\% yeas)). One year before the minaret referendum, the popular initiative "For democratic naturalizations" was put to the ballot. The initiative proposed to make naturalizations a political rather than an administrative act: Municipalities could choose whether to decide on naturalizations in town hall meetings, by an immigration commission or through a popular vote; moreover, decisions could not have been appealed against, making them final and potentially arbitrary. The initiative was rejected with $36.2 \%$ yeas.

\subsection{Separating Islamophobia and Xenophobia}

We identify possible differences in the determinants for xenophobia and Islamophobia by comparing a generally xenophobic referendum with the minaret referendum that targets exclusively Muslims. We select the popular initiative "for democratic naturalizations", held on June 1, 2008, as comparison for three reasons: first, it affects all foreigners alike

\footnotetext{
${ }^{59}$ The share of yes votes were $46 \%$ in the 1970 referendum, $34.2 \%$ in $1974,29.5 \%$, and $33.8 \%$ in the two referenda in 1977.
} 
(and not a specific group of foreigners); second, it addresses a rather generally topic naturalization procedures - and thus voting behavior is not depending strongly on the specific issue; instead naturalization is at heart of the immigration issue. Third, it took place close to the minaret referendum and thus time effects are largely absent. ${ }^{60}$

We regress the difference in approval rates in the minaret referendum and the 2008 naturalization referendum on the same explanatory variables as used in column 5 in table 1. Since most variables in our data set relate to the year 2008, we use the same data for the explanatory variables in this section as in the analysis of the minaret referendum. As a consequence, the results are not influenced by differences in economic and sociodemographic conditions. ${ }^{61}$

Results are reported in table 3. A positive estimate implies that this variable has a more positive effect on the approval rate for the minaret referendum than for the naturalization referendum. If a variable has an estimated positive (negative) effect on the approval rate in the minaret referendum and the differential effect is significantly positive, the effect is stronger (weaker) in the minaret referendum in absolute terms. This implies that Islamophobia is driven more (less) strongly by this variable than xenophobia as the Islamophobic motivation is assumed to be relatively more important in the minaret referendum.

The rural-urban divide is much stronger for the naturalization referendum than for the minaret referendum implying that xenophobia is even more of a rural phenomenon than Islamophobia. The difference in voting pattern between the language groups is much more pronounced for xenophobia than for Islamophobia. While approval rates for the minaret referendum were much higher in the German and even more so in the Italian-speaking parts of Switzerland than in the French-speaking parts, this divergence was even stronger in the naturalization referendum. If the notion is correct that individuals supporting

\footnotetext{
${ }^{60}$ Moreover, results seem to adequately reflect the degree of xenophobia: the share of yes votes amounts to $36.2 \%$ in the 2008 referendum, which is very close to the average vote share of $36.5 \%$ in the referenda against foreign infiltration.

${ }^{61}$ Analogously to section 4, we apply the weighted least squares method using the same weights as in table 1 for comparability reasons.
} 
the two initiatives are motivated by xenophobic as well as by Islamophobic attitudes in both referenda, but that their relative importance differs between the referenda, this finding implies that Islamophobia is more pronounced in the French-speaking parts than in the German and Italian-speaking parts. This result is in line with Danaci (2009) who finds that the French-speaking community is more supportive for naturalization than the German speaking community, but that this finding is reversed if the naturalization of headscarf wearing Muslim women is at issue.

Economic factors work in different directions. Point estimates for unemployment are larger for the naturalization referendum than for the minaret referendum, which would make sense given that the minaret referendum has no labor market implications while the naturalization referendum may well have them. Yet, the difference is not significant at usual levels (t-statistic of -1.48). Higher income reduces approval in the minaret referendum, but surprisingly increases approval in the naturalization referendum. While the first effect is in line with previous research - better off people feel more secure and thus less threatened by foreign influences - the latter effect runs counter to conventional wisdom. One explanation may be that a substantial share of immigration in Switzerland is highskilled. ${ }^{62}$ The educational effects are relatively similar, yet the approval-reducing effect of tertiary education (compared to lower levels of educational attainment) is more pronounced for Islamophobia than for xenophobia. A bigger tertiary sector reduces approval for the minaret referendum but not for the naturalization referendum - thus economic structure has no effect for xenophobia but it does for Islamophobia.

Districts with larger shares of women had significantly lower approval rates for both referenda; yet the effect was much stronger for the naturalization referendum. If we assume that xenophobic and Islamophobic motivations are superimposed in both referenda, but in different relative strengths, then women are far less xenophobic but more Islamophobic than men making the net effect negative in both cases, but less so in the minaret

\footnotetext{
${ }^{62}$ Among the population of the first-generation immigrants in Switzerland, the proportion of people with tertiary education amounted 2015 to $36 \%$, whereas in the population without a migrant background this proportion was only $32.2 \%$. Source: Swiss Labor Force Survey, BFS, https://www.bfs.admin. $\mathrm{ch} / \mathrm{bfs} / \mathrm{de} / \mathrm{home} / \mathrm{statistiken/bevoelkerung/migration-integration/integrationindikatoren/}$ indikatoren/abgeschlossene-ausbildung. assetdetail.300778.html.
} 
referendum. The second result may be explained by the different role of women in Islamic societies, which are commonly perceived as inferior. Districts with more children display higher approval rates in both referenda; this effect is stronger for the naturalization referendum than the minaret referendum. Overall the age pattern is similar.

The presence of Muslims increases the approval rate for the minaret referendum as well as for the naturalization referendum. Surprisingly, the effect is significantly more pronounced for the naturalization referendum than for the minaret referendum. A larger presence of Muslims tends to make the Swiss people significantly more xenophobic; this xenophobia-enhancing effect of a larger Muslim community in a municipality consequently increases the approval for the minaret referendum. The composition of Christian denominations (Catholics and Protestants) has no effect on xenophobia, but a more balanced composition of the denominations reduces the extent of Islamophobia.

In sum, there are distinct differences between the determinants of Islamophobia and xenophobia. We have argued that Islamophobic and xenophobic sentiments are superimposed motivations in both referenda, yet with different relative strengths, and that thus the difference in approval rates allows to draw meaningful conclusions about the determinants of "pure" Islamophobia (which is not directly observable as it is mixed with xenophobic sentiments). Yet, the comparison of the two referenda is meaningful also if one subscribes to the view that the approval to the minaret referendum is driven by Islamophobia only. This comparison then demonstrates that Islamophobia is not just a materialization of xenophobia as the drivers for both sentiments are distinctively different. Islamophobia and xenophobia are shown to be distinct concepts.

\section{Conclusions}

This study analyzes determinants of disapproval for Muslim symbols in Switzerland. It exploits a unique data set, as the minaret referendum is the only outright anti-Islam referendum ever held nationwide in a democratic state. While other referenda may also capture anti-Islamic sentiments, they are always intertwined with additional - often economic - concerns and have distributional consequences (as in the case of immigration 
policy). This disallows to identify the determinants of Islamophobia. Survey evidence potentially suffers from severe answering biases. The minaret referendum proves this point quite clearly as opinion polls prior to the referendum were impressively off the mark.

The minaret referendum therefore provides a unique opportunity to analyze the determinants of Islamophobia. Our investigation shows that education, income, and employment status exert significant influences on the disapproval of Muslim symbols. It also exhibits large differences between the language groups in Switzerland, indicating that not only socio-economic status but also culture strongly matters. The cultural differences within Switzerland make the Swiss case especially attractive - our finding suggests that Islamophobia may not be uniform across democratic Western states. Moreover, we show that approval for the minaret referendum increases with the number of Muslims in a community, which corroborates the 'religious threat' hypothesis. We also show that Islamophobia has different drivers than general xenophobia or the support for the right-wing populist party that initiated the referendum in the election.

Islamophobia and xenophobia remain highly relevant in Switzerland. The minaret referendum was followed by further xenophobic popular initiatives: "For the expulsion of foreign criminals" ("Für die Ausschaffung krimineller Ausländer", 2010), "Against mass immigration" ("Gegen Masseneinwanderung", 2014), and "For enforcement of the expulsion of foreign criminals" ("Zur Durchsetzung der Ausschaffung krimineller Ausländer", 2016). At the cantonal level, the canton Ticino has forbidden the full body veil in the referendum held on September 22, 2013. ${ }^{63}$

Yet, Islamophobia is highly virulent throughout Europe, if not throughout the Western world. The voting results for populist nationalistic parties in Europe in the recent elections as well as large case evidence prove that Islamophobia is not a phenomenon limited to Switzerland. For instance, there were initiatives to prohibit minaret buildings in Völklingen (Germany). ${ }^{64}$ In France, 2011 the use of burka was prohibited. Austria followed in 2017. Recent terror attacks in Paris, London, Berlin, Brussels and elsewhere

\footnotetext{
${ }^{63}$ http://www.spiegel.de/politik/ausland/schweiz-tessin-stimmt-fuer-burka-verbot-a$923774 . \mathrm{html}$.

${ }^{64}$ https://www.welt.de/politik/deutschland/article6382184/Das-Saarland-hat-seineneigenen-Minarett-Streit.html.
} 
and the large influx of migrants from Muslim states may have fueled existing resentments. Due to the specific features of its political system Switzerland provides a unique opportunity to study the determinants of Islamophobia, but Islamophobia is by no means a unique feature of the Swiss population. The experiences of the minaret referendum may thus be informative for other European countries as well. 


\section{References}

Alesina, A., R. Baqir, and W. Easterly (1999). "Public Goods and Ethnic Divisions". Quarterly Journal of Economics 114(4), 1243-1284.

Alesina, A., A. Devleeschauwer, W. Easterley, S. Kurlat and R. Wacziarg (2003). "Fractionalization". Journal of Economic Growth 8, 155-194.

Allenbach, B. and M. Sökefeld (2010). "Muslime in der Schweiz". Seismo Verlag, Zürich.

Allport, G. W. (1954). "The Nature of Prejudice". Addison-Wesley, New York.

Amemiya, T. (1985). "Advanced Econometrics". Harvard University Press, Cambridge, Mass.

Amir, Y. (1969). "Contact Hypothesis in Ethnic Relations". Psychological Bulletin 71, 319-342.

Arzheimer, K. (2009). "Contextual Factors and the Extreme Right Vote in Western Europe, 1980-2002". American Journal of Political Science 53(2), 259-275.

Baum, C. F. (2008). "Stata Tip 63: Modeling Proportions". The Stata Journal (2008) 8, Number 2, 299-303.

BFS (2003). "Eidgenössische Volkszählung 2000, Bevölkerungsstruktur, Hauptsprache und Religion". Neuenburg.

Boisjoly, J., G. J. Duncan, M. Kremer, D. M. Levy, and J. Eccles (2006). "Empathy or Apathy? The Impact of Diversity". American Economic Review 96(5), 1890-905.

Bowler, S., S. Nicholson, and G. Segura (2006). "Earthquakes and Aftershocks: Race, Direct Democracy, and Partisan Change". American Journal of Political Science 50(1), 146-59.

Büchi, C. (2003). "Röstigraben. Das Verhältnis zwischen deutscher und französischer Schweiz. Geschichte und Perspektiven”. Verlag Neue Zürcher Zeitung, Zürich. 
Burden, B. C. and D. C. Kimball (1998). "A New Approach to the Study of Ticket Splitting". The American Political Science Review 92(3), 533-544.

Cameron, A. C. and P. K. Trivedi (2005). "Microeconometrics: Methods and Applications". Cambridge University Press, New York.

Cho W. K. T. and B. J. Gaines (2004). "The Limits of Ecological Inference: The Case of Split-Ticket Voting". American Journal of Political Science 48(1), 152-171.

Collingwood, L., Oskooii, K., Garcia-Rios, S., and Barreto, M. (2016). "eiCompare: Comparing Ecological Inference Estimates across EI and EI:RxC". The $R$ Journal Vol. 8/2, 92-101.

Danaci, D. (2009). “Turning Switzerland's 'Röstigraben' Upside Down: New Evidence from the Political Divide between Swiss-German and French Speaking Citizens". Working Paper. University of Bern, Institute of Political Science, mimeo.

Dixon, J. and M. Rosenbaum (2004). "Nice to Know You? Testing Contact, Cultural, and Group Threat Theories of Anti-black and Anti-Hispanic Stereotypes". Social Science Quarterly 85(2), 257-80.

Duncan, O. D. and B. Davis (1953). "An Alternative to Ecological Correlation". American Sociological Review 18, 665-666.

Dustmann, C. and I. Preston (2001). "Attitudes to Ethnic Minorities, Ethnic Context and Location Decisions". Economic Journal 111(470), 353-373.

Dustmann, C. and I. Preston (2007). "Racial and Economic Factors in Attitudes to Immigration". The B.E. Journal of Economic Analysis 85 Policy 7(1), Article 62.

Easterley, W. and R. Levin (1997). “Africa's Growth Tragedy: Policies and Ethnic Divisions". Quarterly Journal of Economics 111(4), 1203-1250.

EKM (2010). "Muslime in der Schweiz". Eidgenössische Kommission für Migrationsfragen (EKM), Bern, www.ekm.admin.ch/de/dokumentation/doku/mat_muslime_d. pdf. 
Ferree, K. E. (2004) Iterative approaches to RxC ecological inference problems: where they can go wrong and one quick fix. Political Analysis 12(2), 143-159.

Fertig, M. and C. Schmidt (2010). "Attitudes Towards Foreigners and Jews in Germany: Identifying the Determinants of Xenophobia in a Large Opinion Survey". Review of Economics of the Household, doi: 10.1007/s11150-009-9084-3.

Freedman, D. A., S. P. Klein, J. Sacks, C. A. Smyth, and C. G. Everett (1991). "Ecological Regression and Voting Rights". Evaluation Review 15, 673-711.

Freedman, D. A., S. P. Klein, M. Ostland, and M. Roberts (1998[1]). "On 'Solutions' to the Ecological Inference Problem". Technical Report No. 515, Statistics Department, UC Berkeley, CA 94720, http://www.stat.berkeley.edu/ census/515. pdf.

Freedman, D.A., S. P. Klein, M. Ostland, and M. R. Roberts (1998[2]). "Review of A Solution to the Ecological Inference Problem, by G. King”. Journal of the American Statistical Association 93, 1518-1522.

Gidengil, E., M. Hennigar, A. Blais and N. Nevitte (2005). "Explaining The Gender Gap in Support for the New Right". Comparative Political Studies 38(10), 1171-1195.

Giger, N. (2009). "Towards a modern gender gap in Europe?: A Comparative Analysis of Voting Behavior in 12 Countries". The Social Science Journal 46(3), 474-492.

Giles, M. W. and K. Hertz (1994). "Racial Threat and Partisan Identification". American Political Science Review 88(2), 317-26.

Givens, T. (2002). "The Role of Socio-Economic Factors in the Success of Extreme Right Parties". In M. Schain, A. Zolberg and P. Hossay (Eds.), Shadows over Europe: The Development and Impact of the Extreme Right in Western Europe. Palgrave, New York.

Glaser, J. (1994). "Back to the Black Belt: Racial Environment and White Racial Attitudes in the South". Journal of Politics 56(1), 21-41. 
Gorodzeisky A, Semyonov M. (2009). "Terms of Exclusion: Public Views Towards Admission and Allocation of Rights to Immigrants in European Countries". Ethnic and Racial Studies 32(1),401-23.

Golder, M. (2003). "Explaining Variation in the Success of Extreme Right-Wing Parties in Western Europe". Comparative Political Studies 36, 432-466.

Goodman, L. A. (1953). "Ecological Regressions and Behavior of Individuals". American Sociological Review 18, 663-664.

Green, W. H. (2002). "Econometric Analysis", 5th ed., Prentice-Hall International, Inc.

Green, D., J. Glaser, and A. Rich (1998). "From Lynching to Gay Bashing: The Elusive Connection Between Economic Conditions and Hate Crime". Journal of Personality and Social Psychology 75, 82-92.

Gschwend, T. (2006). "Ökologische Inferenz". In J. Behnke, T. Gschwend, D. Schindler, and K.-U. Schnapp (Eds.), Methoden der Politikwissenschaft: Neure qualitative und quantitative Analyseverfahren. Baden-Baden, Nomos, 227-237.

Habyarimana, J., M. Humphreys, D. Posner, and J. Weinstein (2007). "Why Does Ethnic Diversity Undermine Public Goods Provision?" American Political Science Review 101(4), 709-725.

Helbling, M. (2008). "Islamophobia in Switzerland: A New Phenomenon or a New Name for Xenophobia?" mimeo, Department of political science, University of Zurich http://www.allacademic.com//meta/p_mla_apa_research_citation/2/6/8/3/ 7/pages268377/p268377-1.php.

Hermann, M. and H. Leuthold (2003). "Atlas der politischen Landschaften: ein weltanschauliches Porträt der Schweiz”. vdf Hochschulverlag AG, Zürich.

Hjerm, M. (2001). "Education, Xenophobia and Nationalism: a Comparative Analysis". Journal of Ethnic and Migration Studies 27(1), 37-60. 
Honaker, J. (2008). "Unemployment and Violence in Northern Ireland: A Missing Data Model for Ecological Inference". mimeo, UCLA, http://tercer.bol.ucla.edu/ papers/ni.pdf.

Husbands, Ch. (2002). "How to Tame the Dragon, or What Goes Around Comes Around: A Critical Review of Some Major Contemporary Attempts to Account for Extreme-Right Racist Politics in Western Europe". In M. Schain, A. Zolberg and P. Hossay (Eds.) Shadows over Europe: The Development and Impact of the Extreme Right in Western Europe, Palgrave, New York.

Jackman, R. and K. Volpert (1996). "Conditions Favouring Parties of the Extreme Right in Western Europe". British Journal of Political Science 26, 501-521.

Jefferson, P. N. and Pryor, F. L. (1999). "On the Geography of Hate". Economics Letters 65(3), 389-395.

Kessler, A. and G. Freeman (2005). "Support for Extreme Right-Wing Parties in Western Europe: Individual Attributes, Political Attitudes, and National Context". Comparative European Politics 3, 261-288.

Key, V. O., Jr. (1949). "Southern Politics - In State and Nation". University of Tennessee Press, Knoxville, TN.

King, G. (1997). "A Solution to the Ecological Inference Problem. Reconstructing Individual Behavior from Aggregate Data”. Princeton University Press.

King, G. (1999). "The Future of Ecological Inference Research: A Reply to Freedman et al.". Journal of the American Statistical Association 94, 352-355, http://gking. harvard.edu/files/gking/files/reply.pdf.

King, G., O. Rosen, and M. A. Tanner (Eds.) (2004). "Ecological Inference: New Methodological Strategies". Cambridge University Press.

Kirchgässner, G. (2010a). "Direkte Demokratie und Menschenrechte". In L. P. Feld et al. (Eds.) Jahrbuch für direkte Demokratie 2009. Baden-Baden, Nomos, 66-89. 
Kirchgässner, G. (2010b). "Zu einigen Problemen der direkten Volksrechte". In P. Neumann (Eds.) Sachunmittelbare Demokratie im interdisziplinären und internationalen Kontext, Baden-Baden, Nomos, 137-161.

Kitschelt, H. (1995). "The Radical Right in Western Europe: A Comparative Analysis". University of Michigan Press, Ann Arbor.

Knigge, P. (1998). "The Ecological Correlates of Right-Wing Extremism in Western Europe". European Journal of Political Research 34, 249-279.

Krueger, A. B. and J. Maleckova (2003). "Education, Poverty and Terrorism: Is There a Causal Connection?" Journal of Economic Perspectives 17(4), 119-144.

Krueger, A. and J. Pischke (1997). "A Statistical Analysis of Crime Against Foreigners in Unified Germany". Journal of Human Resources, 182-209.

Kühnel, S. and J. Leibold (2007). "Islamophobie in der deutschen Bevölkerung: Ein neues Phänomen oder nur ein neuer Namen? Ergebnisse von Bevölkerungsumfragen zur Gruppenbezogenen Menschenfeindlichkeit 2003 bis 2005”. In M. Wohlrab-Sahr and L. Tezcan (Eds.) Konfliktfeld Islam in Europa. Nomos, Baden-Baden, 135-154.

Langer, L. (2010). "Panacea or Pathetic Fallacy? The Swiss Ban on Minarets". Vanderbilt Journal of Transnational Law 43(4), 863-951.

Leemann, L. and Ph. Leimgruber (2009). "Ecological Inference and 113 Votes". Prepared for the Annual Conference of the Swiss Political Science Association, St. Gallen.

Lewis-Beck, M. and G. Mitchell (1993). "French Electoral Theory: The National Front Test". Electoral Studies 12, 112-127.

Liu, B. (2001). "The Positive Effect of Black Density on White Crossover Voting: Reconsidering the Social Interaction Theory". Social Science Quarterly 82(3), 602-615. 
Longchamp, C., L. Kopp, J. Kocher, and S. Ratelband-Pally (2009). "'Minarett-Initiative': Das Nein überwiegt - SVP Wählerschaft dafür". gfs.bern, http://modules.drs. ch/data/attachments/2009/091023_gfs_abstimmungsbarometer.pdf.

Lubbers, M., M. Gijsberts, and P. Scheepers (2002). "Extreme Right Wing Voting in Western Europe". European Journal of Political Research 41(3), 345-378.

Maddala, G. S. (1983). "Limited Dependent and Qualitative Variables in Econometrics". Cambridge University Press, Cambridge/UK.

Mayda, A.M. (2006). "Who is Against Immigration? A Cross-country Investigation of Individual Attitudes Toward Immigrants". The Review of Economics and Statistics $88(3), 510-530$.

McFadden, D. (1973). "Conditional Logit Analysis of Qualitative Choice Behavior". In P. Zarembka (Eds.) Frontiers in Econometrics. Academic Press, New York.

McFadden, D. and F. Reid (1975). "Aggregate Travel Demand Forecasting from Disaggregated Behavioral Models". Transportation Research Record: Travel Behavior and Values 534, 24-37.

Miguel, E. and M.K. Gugerty (2005). "Ethnic Diversity, Social Sanctions, and Public Goods in Kenya". Journal of Public Economics 89, 2325-2368.

Montalvo, J. and M. Reynal-Querol (2005). "Ethnic Diversity and Economic Development". Journal of Development Economics 76(2), 293-323.

Pacillo, V. (2009). "Federalism and Religions in the Swiss Confederation's Institutional Dynamics". Journal of Church and State 51(4), 617-633.

Papke, L. and J. Wooldridge (1996). "Econometric Methods for Fractional Response Variable with an Application to 401(K) Plan Participation Rates". Journal of Applied Econometrics 11, 619-632.

Pindyck, R. and D. Rubinfeld (1991). "Econometric Models and Economic Forecast", 3rd ed. McGraw-Hill, New York. 
Pratto, F., L. Stallworth and J. Sidanius (1997). "The Gender Gap: Differences in Political Attitudes and Social Dominance Orientation". British Journal of Social Psychology 36(1), 49-68.

Quillian L. (1995). "Prejudice as a Response to Perceived Threat: Population Composition and Anti-immigrant and Racial Prejudice in Europe". American Sociology Review 60(4), 586-611.

Rindermann, H., C. Flores-Mendozab, and M. Woodley (2012). "Political Orientations, Intelligence and Education". Intelligence 40(2), 217-255.

Rosen, O., W. Jiang, G. King, and M. A. Tanner (2001). "Bayesian and Frequentist Inference for Ecological Inference: The RxC Case". Statistica Neerlandica 55(2), 134-156.

Rydgren, J. (2007). "The Sociology of the Radical Right". Annual Review of Sociology 33, 241-62.

Sichone, O. (2008). "Xenophobia and Xenophilia in South Africa: African Migrants in Cape Town". In P.Werbner (Eds.) Anthropology and the New Cosmopolitanism. Oxford, Berg.

Schoon, I., H. Cheng, C. Gale, D. Batty, and I. Deary (2010). "Social Status, Cognitive Ability, and Educational Attainment as Predictors of Liberal Social Attitudes and Political Trust". Intelligence 38(1), 144-150.

Schweizerischer Bundesrat (2008). "Botschaft zur Volksinitiative 'Gegen den Bau von Minaretten' [Government Report on the Ballot Initiative 'Against the Construction of Minarets']". Bundesblatt [BBl] 7603, Aug. 27, 2008.

Stankov, L. (2009). "Conservatism and Cognitive Ability". Intelligence 37(3), 294-304.

Stein, R. M., S. S. Post, and A. L. Rinden (2000). "Reconciling Context and Contact Effects on Racial Attitudes". Political Research Quarterly 53(2), 285-303. 
Stolz, J. (2005). "Islamophobia. A Test of Four Theories Based on the Case of a Swiss City". Swiss Journal of Sociology 31(3), 547-566.

Stüssi, M. (2008). "Banning of Minarets: Addressing the Validity of a Controversial Swiss Popular Initiative". Religion and Human Rights 3(2), 135-153.

Schweizerische Studiengesellschaft für Raumordnung und Regionalpolitik (2006). "Die ländlichen Räume der Schweiz". http://www.rorep.ch/pdf/ROREP_LandlicheRaume.pdf.

Tourangeau, R., and T. Yan (2007). "Sensitive Questions in Surveys". Psychological Bulletin 133(5), 859-883.

Voss, S. (1996). "Beyond Racial Threat: Failure of an Old Hypothesis in the New South". Journal of Politics 58(4), 1156-70.

Wakefield, J. (2004). "Ecological inference for 2x2 tables (with discussion)". Journal of the Royal Statistical Society: Series A (Statistics in Society) 167(3), 385-445.

Wike, R., B. Stokes and K. Simmons (2016). "Europeans Fear Wave of Refugees Will Mean More Terrorism, Fewer Jobs". Pew Research Center Report, http://assets. pewresearch.org/wp-content/uploads/sites/2/2016/07/14095942/Pew-ResearchCenter-EU-Refugees-and-National-Identity-Report-FINAL-July-11-2016 .pdf.

Zak, P. and S. Knack (2001). "Trust and Growth". Economic Journal 111, 295-321. 


\section{Tables}

Table 1: Regression results (WLS), dependent variable: APPROVAL

\begin{tabular}{|c|c|c|c|c|c|c|}
\hline Variable & (1) & $(2)$ & (3) & (4) & (5) & $(5 a)$ \\
\hline \multirow[t]{2}{*}{ Constant } & 0.873 & 1.081 & 0.458 & 0.776 & 0.603 & 0.588 \\
\hline & $(3.63)$ & $(6.57)$ & $(2.97)$ & $(4.82)$ & $(3.60)$ & $(3.40)$ \\
\hline \multirow[t]{2}{*}{ PERIPHERY } & $0.138^{* * *}$ & $0.140^{* * *}$ & $0.122^{* * *}$ & $0.112^{* * *}$ & $0.063^{* * *}$ & $0.059 * * *$ \\
\hline & $(7.52)$ & $(9.24)$ & $(8.46)$ & $(7.54)$ & $4.18)$ & $(3.84)$ \\
\hline \multirow[t]{2}{*}{ RURAL } & $0.432^{* * *}$ & $0.152^{* * *}$ & $0.117^{* * *}$ & $0.131^{* * *}$ & $0.074^{* * *}$ & $0.073 * * *$ \\
\hline & $(16.11)$ & $(7.84)$ & $(6.39)$ & $(6.97)$ & $(3.87)$ & $(3.76)$ \\
\hline \multirow[t]{2}{*}{ GERMAN } & $0.160^{* * *}$ & $0.371^{* * *}$ & $0.253^{* * *}$ & $0.373^{* * *}$ & $0.408^{* * *}$ & $0.408^{* * *}$ \\
\hline & $(12.09)$ & $(23.28)$ & $(13.56)$ & $(19.98)$ & $(20.50)$ & $(20.74)$ \\
\hline \multirow[t]{2}{*}{ ITALIAN } & $0.534^{* * *}$ & $0.630^{* * *}$ & $0.749^{* * *}$ & $0.652^{* * *}$ & $0.680 * * *$ & $0.682^{* * *}$ \\
\hline & $(13.07)$ & $(24.01)$ & $(29.64)$ & $(26.05)$ & $(25.66)$ & $(25.38)$ \\
\hline \multirow[t]{2}{*}{ RHAETO-ROMANIC } & $-0.318^{* *}$ & $-0.303^{* * *}$ & $-0.394^{* * *}$ & $-0.296^{* * *}$ & $-0.217 * * *$ & $-0.217 * * *$ \\
\hline & $(-2.38)$ & $(-3.77)$ & $(-5.28)$ & $(-3.84)$ & $(-2.84)$ & $(-2.82)$ \\
\hline \multirow[t]{2}{*}{ WOMEN } & & $-0.049 * * *$ & $-0.041^{* * *}$ & $-0.037^{* * *}$ & $-0.045 * * *$ & $-0.046^{* * *}$ \\
\hline & & $(-23.36)$ & $(-23.63)$ & $(-20.69)$ & $(-21.67)$ & $(-22.00)$ \\
\hline \multirow[t]{2}{*}{ EDUCATION 1} & & $0.027^{* * *}$ & $0.026^{* * *}$ & $0.025^{* * *}$ & $0.027^{* * *}$ & $0.027^{* * *}$ \\
\hline & & $(26.17)$ & $(25.49)$ & $(24.82)$ & $(25.93)$ & $(26.39)$ \\
\hline \multirow[t]{2}{*}{ EDUCATION 2} & & $0.031^{* * *}$ & $0.025^{* * *}$ & $0.028^{* * *}$ & $0.029 * * *$ & $0.029 * * *$ \\
\hline & & $(24.44)$ & $(20.40)$ & $(23.72)$ & $(23.02)$ & $(22.61)$ \\
\hline \multirow[t]{2}{*}{ UNEMPLOYMENT } & & $0.027 * * *$ & $0.012^{* *}$ & $0.014^{* * *}$ & $0.016^{* * *}$ & $0.016 * * *$ \\
\hline & & $(5.38)$ & $(2.16)$ & $(2.57)$ & $(2.97)$ & $(3.01)$ \\
\hline \multirow[t]{2}{*}{ INCOME } & & $-0.032^{* * *}$ & $-0.035^{* * *}$ & $-0.017^{* *}$ & $-0.022 * * *$ & $-0.020 * * *$ \\
\hline & & $(-4.27)$ & $(-4.71)$ & $(-2.31)$ & $(-2.94)$ & $(-2.61)$ \\
\hline \multirow[t]{2}{*}{ CRIME } & & $-0.003^{* * *}$ & $-0.002^{* * *}$ & $-0.002^{* * *}$ & $-0.001 * * *$ & $-0.001 * * *$ \\
\hline & & $(-14.53)$ & $(-14.29)$ & $(-8.50)$ & $(-3.89)$ & $(-4.14)$ \\
\hline \multirow[t]{2}{*}{ RELIGION MIX } & & & & $-0.026^{*}$ & $-0.032^{* *}$ & $-0.032 * *$ \\
\hline & & & & $(-1.95)$ & $(-2.45)$ & $(-2.43)$ \\
\hline \multirow[t]{2}{*}{ CREEDLESS } & & $-0.004^{* * *}$ & & & & \\
\hline & & $(-3.52)$ & & & & \\
\hline \multirow[t]{2}{*}{ PROTESTANTS } & & & $0.048^{* *}$ & & & \\
\hline & & & $(2.50)$ & & & \\
\hline \multirow[t]{2}{*}{ CATHOLICS } & & & $0.034^{* *}$ & & & \\
\hline & & & $(2.12)$ & & & \\
\hline \multirow[t]{2}{*}{ MUSLIMS 2000} & & & 0.002 & $0.005^{* *}$ & $0.006^{* *}$ & \\
\hline & & & $(0.52)$ & $(1.99)$ & $(2.38)$ & \\
\hline \multirow[t]{2}{*}{ MUSLIMS 2010} & & & & & & $0.010^{* *}$ \\
\hline & & & & & & $(2.52)$ \\
\hline
\end{tabular}




\begin{tabular}{|c|c|c|c|c|c|c|}
\hline Variable & $(1)$ & $(2)$ & $(3)$ & $(4)$ & $(5)$ & $(5 a)$ \\
\hline \multirow[t]{2}{*}{ MIGRATION BALANCE } & & & & $-0.048^{* * *}$ & $-0.037 * * *$ & $-0.035^{* * *}$ \\
\hline & & & & $(-12.13)$ & $(-8.96)$ & $(-8.27)$ \\
\hline \multirow[t]{2}{*}{ TERTIARY SECTOR } & & & & $-0.003^{* * *}$ & $-0.002 * * *$ & $-0.002^{* * *}$ \\
\hline & & & & $(-8.80)$ & $(-6.05)$ & $(-5.89)$ \\
\hline \multirow[t]{2}{*}{ AGE 0-19 } & & & & & $0.014^{* * *}$ & $0.015 * * *$ \\
\hline & & & & & $(7.23)$ & $(7.41)$ \\
\hline \multirow[t]{2}{*}{ AGE 20-39 } & & & & & $-0.013 * * *$ & $-0.013 * * *$ \\
\hline & & & & & $(-7.14)$ & $(-7.10)$ \\
\hline \multirow[t]{2}{*}{ AGE 40-59 } & & & & & $0.009 * * *$ & $0.009 * * *$ \\
\hline & & & & & $(3.60)$ & $(3.51)$ \\
\hline \multirow[t]{2}{*}{ FOREIGNERS } & & & $-0.003^{* * *}$ & & & \\
\hline & & & $(-2.82)$ & & & \\
\hline \multirow[t]{2}{*}{ SVP } & & & $0.010^{* * *}$ & & & \\
\hline & & & $(18.86)$ & & & \\
\hline \multirow[t]{2}{*}{ TURNOUT } & & $0.004^{* * *}$ & & & & \\
\hline & & $(4.80)$ & & & & \\
\hline Observations & 2,612 & 2,603 & 2,592 & 2,603 & 2,557 & 2,476 \\
\hline$R^{2}$ & 0.21 & 0.73 & 0.76 & 0.75 & 0.76 & 0.76 \\
\hline Adjusted $R^{2}$ & 0.21 & 0.73 & 0.76 & 0.75 & 0.76 & 0.76 \\
\hline F-statistic & 136.89 & 531.85 & 519.62 & 511.00 & 449.10 & 430.41 \\
\hline
\end{tabular}

Notes: t-values in parentheses. ${ }^{* * *}$ indicates $1 \%$ significance level, ${ }^{* *}$ indicates $5 \%$ significance level, ${ }^{*}$ indicates $10 \%$ significance level. For data description s. Table A.1. 
Table 2: Regression results (WLS) with and without Ecological Inference

\begin{tabular}{|c|c|c|c|}
\hline$\overline{\text { Variable }}$ & Basic model & EI model 1 & EI model 2 \\
\hline Constant & $0.603(3.60)$ & $0.818(4.78)$ & $0.868(4.76)$ \\
\hline PERIPHERY & $0.063^{* * *}(4.18)$ & $0.105^{* * *}(6.78)$ & $0.099^{* * *}(6.04)$ \\
\hline RURAL & $0.074^{* * *}(3.87)$ & $0.110^{* * *}(5.63)$ & $0.130^{* * *}(6.34)$ \\
\hline GERMAN & $0.408^{* * *}(20.50)$ & $0.437 * * *(21.42)$ & $0.464^{* * *}(23.15)$ \\
\hline ITALIAN & $0.680^{* * *}(25.66)$ & $0.712^{* * *}(25.95)$ & $0.718^{* * *}(24.97)$ \\
\hline RHAETO-ROMANIC & $-0.217^{* * *}(-2.84)$ & $-0.061(-0.78)$ & $-0.021(-0.25)$ \\
\hline RELIGION MIX & $-0.032^{* *}(-2.45)$ & $-0.035^{* * *}(-2.64)$ & $-0.049 * * *(-3.57)$ \\
\hline EDUCATION 1 & $0.027 * * *(25.93)$ & $0.026^{* * *}(23.82)$ & $0.018^{* * *}(19.37)$ \\
\hline EDUCATION 2 & $0.029^{* * *}(23.02)$ & $0.025^{* * *}(20.22)$ & $0.013^{* * *}(13.77)$ \\
\hline WOMEN & $-0.045^{* * *}(-21.67)$ & $-0.031^{* * *}(-17.74)$ & $-0.024^{* * *}(-14.28)$ \\
\hline UNEMPLOYMENT & $0.016^{* * *}(2.97)$ & $0.015^{* * *}(2.72)$ & $\mathbf{0 . 0 2 4 * * *}(3.23)$ \\
\hline INCOME & $-0.022 * * *(-2.94)$ & $-0.045 * * *(-5.91)$ & $-0.062^{* * *}(-8.09)$ \\
\hline CRIME & $-0.001 * * *(-3.89)$ & $-0.001^{* * *}(-5.52)$ & $-0.002^{* * *}(-9.18)$ \\
\hline MIGR. BALANCE & $-0.037 * * *(-8.96)$ & $-0.032^{* * *}(-7.40)$ & $-0.060 * * *(-14.44)$ \\
\hline TERTIARY & $-0.002 * * *(-6.05)$ & $-0.003^{* * *}(-8.33)$ & $-0.003^{* * *}(-8.95)$ \\
\hline MUSLIMS 2000 & $0.006^{* *}(2.38)$ & $0.010 * * *(3.63)$ & $0.010^{* * *}(3.52)$ \\
\hline AGE 0-19 & $0.014^{* * *}(7.23)$ & $0.010 * * *(5.18)$ & $0.008 * * *(5.37)$ \\
\hline AGE 20-39 & $-0.013^{* * *}(-7.14)$ & $-0.013 * * *(-6.85)$ & $0.0003(0.15)$ \\
\hline AGE 40-59 & $0.009^{* * *}(3.60)$ & $0.002(0.82)$ & $\mathbf{0 . 0 1 2} * * *(6.98)$ \\
\hline Observations & 2,557 & 2,557 & 2,499 \\
\hline$R^{2}$ & 0.76 & 0.75 & 0.73 \\
\hline Adj. $R^{2}$ & 0.76 & 0.75 & 0.72 \\
\hline F-Statistic & 449.10 & 418.75 & 366.23 \\
\hline
\end{tabular}

Notes: Dependent variable: APPROVAL, t-values in parentheses. The estimates obtained using the variables estimated by the EI method are shown in bold. 
Table 3: Regression results (WLS) for the referenda 2009, 2008 and the difference in approval rates.

\begin{tabular}{llll}
\hline \hline Variable & $\mathbf{( 1 )}$ & $\mathbf{( 2 )}$ & $\mathbf{( 3 )}$ \\
\hline Constant & $0.603(3.60)$ & $-0.076(-0.37)$ & $0.681(4.21)$ \\
PERIPHERY & $0.063^{* * *}(4.18)$ & $0.053^{* * *}(2.85)$ & $0.011(0.72)$ \\
RURAL & $0.074^{* * *}(3.87)$ & $0.128^{* * *}(5.47)$ & $-0.054^{* * *}(-2.94)$ \\
GERMAN & $0.408^{* * *}(20.50)$ & $1.026^{* * *}(42.08)$ & $-0.618^{* * *}(-32.18)$ \\
ITALIAN & $0.680^{* * *}(25.66)$ & $1.143^{* * *}(35.21)$ & $-0.463^{* * *}(-18.12)$ \\
RHAETO-ROMANIC & $-0.217^{* * *}(-2.84)$ & $0.334^{* * *}(3.57)$ & $-0.549^{* * *}(-7.47)$ \\
RELIGION MIX & $-0.032^{* *}(-2.45)$ & $-0.005(-0.30)$ & $-0.027^{* *}(-2.16)$ \\
EDUCATION 1 & $0.027^{* * *}(25.93)$ & $0.018^{* * *}(14.01)$ & $0.009^{* * *}(9.08)$ \\
EDUCATION 2 & $0.029^{* * *}(23.02)$ & $0.013^{* * *}(8.81)$ & $0.015^{* * *}(12.68)$ \\
WOMEN & $-0.045^{* * *}(-21.67)$ & $-0.075^{* * *}(-29.26)$ & $0.030^{* * *}(14.70)$ \\
UNEMPLOYMENT & $0.016^{* * *}(2.97)$ & $0.024^{* * *}(3.59)$ & $-0.008(-1.48)$ \\
INCOME & $-0.022^{* * *}(-2.94)$ & $0.060^{* * *}(6.44)$ & $-0.083^{* * *}(-11.23)$ \\
CRIME & $-0.0008^{* * *}(-3.89)$ & $-0.0014^{* * *}(-5.71)$ & $0.0006^{* * *}(3.22)$ \\
MIGRATION BALANCE & $-0.037^{* * *}(-8.96)$ & $-0.021^{* * *}(-4.12)$ & $-0.016^{* * *}(-4.05)$ \\
TERTIARY & $-0.002^{* * *}(-6.05)$ & $-0.001(-1.33)$ & $-0.002^{* * *}(-4.58)$ \\
MUSLIMS 2000 & $0.006^{* *}(2.38)$ & $0.016^{* * *}(4.73)$ & $-0.009^{* * *}(-3.54)$ \\
AGE 0-19 & $0.014^{* * *}(7.23)$ & $0.026^{* * *}(11.08)$ & $-0.012^{* * *}(-6.57)$ \\
AGE 20-39 & $-0.013^{* * *}(-7.14)$ & $-0.0002(-0.08)$ & $-0.013^{* * *}(-7.31)$ \\
AGE 40-59 & $0.009^{* * *}(3.60)$ & $0.014^{* * *}(4.65)$ & $-0.005^{* *}(-2.18)$ \\
\hline Observations & 2,557 & 2,555 & 2,555 \\
$R^{2}$ & 0.76 & 0.88 & 0.88 \\
Adj. $R^{2}$ & 0.76 & 0.88 & 0.88 \\
F-Statistic & 449.10 & 1015.90 & 994.13 \\
\hline \hline
\end{tabular}

Notes: (1) Results for the referendum 2009; dependent variable: APPROVAL. (2) Results for the referendum 2008; dependent variable: APPROVAL 2008. (3) Dependent variable: difference APPROVAL APPROVAL 2008; t-values in parentheses. 


\section{Appendix}

Table A.1: Descriptive statistics for the estimation sample

\begin{tabular}{|c|c|c|c|c|c|c|c|}
\hline Variable name & "Variable description & unit & observations & Mean & Std. dev. & $\overline{\min }$ & 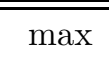 \\
\hline APPROVAL & $\begin{array}{l}\text { Approval rate in minaret referendum } \\
\text { for each municipality }\end{array}$ & logit & 2,612 & 0.556 & 0.495 & -1.099 & 3.178 \\
\hline APPROVAL 2008 & $\begin{array}{l}\text { Approval rate in democratic naturalization } \\
\text { referendum for each municipality }\end{array}$ & logit & 2,610 & -0.510 & 0.676 & -3.714 & 2.037 \\
\hline UNEMPLOYMENT & $\begin{array}{l}\text { Unemployment rate, } \\
\text { annual average }\end{array}$ & percent & 2,610 & 2.659 & 1.609 & 0 & 29.300 \\
\hline INCOME & Annual net per capita income & $10,000 \mathrm{SFr}$ & 2,611 & 3.000 & 0.745 & 0.839 & 10.725 \\
\hline WOMEN & Share of women in the municipality & percent & 2,612 & 50.107 & 1.897 & 24.366 & 62.500 \\
\hline WOMEN EI & $\begin{array}{l}\text { Share of women on the voting population } \\
\text { estimated by EI-procedure }\end{array}$ & percent & 2,612 & 56.290 & 3.068 & 26.287 & 72.057 \\
\hline FOREIGNERS & Share of foreign persons & percent & 2,612 & 12.863 & 9.157 & 0 & 61.598 \\
\hline PRIMARY SECTOR & Share of employees in primary sector & percent & 2,612 & 23.353 & 22.527 & 0 & 100 \\
\hline SECONDARY SECTOR & Share of employees in secondary sector & percent & 2,612 & 27.483 & 18.116 & 0 & 100 \\
\hline TERTIARY SECTOR & Share of employees in tertiary sector & percent & 2,612 & 49.171 & 21.634 & 0 & 100 \\
\hline AGGLOMERATION CORE & $\begin{array}{l}\text { 1: municipality belongs to } \\
\text { agglomeration cores; 0: else }\end{array}$ & $\begin{array}{l}\text { dummy } \\
\text { variable }\end{array}$ & 2,612 & 0.024 & 0.153 & 0 & 1 \\
\hline PERIPHERY & $\begin{array}{l}\text { 1: municipality belongs to } \\
\text { agglomeration peripheries; 0: else }\end{array}$ & $\begin{array}{l}\text { dummy } \\
\text { variable }\end{array}$ & 2,612 & 0.329 & 0.470 & 0 & 1 \\
\hline RURAL & $\begin{array}{l}\text { 1: municipality belongs to } \\
\text { rural areas; 0: else }\end{array}$ & $\begin{array}{l}\text { dummy } \\
\text { variable }\end{array}$ & 2,612 & 0.647 & 0.478 & 0 & 1 \\
\hline GERMAN & $\begin{array}{l}\text { 1: municipality belongs to Swiss-German } \\
\text { speaking part of Switzerland; 0: else }\end{array}$ & $\begin{array}{l}\text { dummy } \\
\text { variable }\end{array}$ & 2,612 & 0.605 & 0.489 & 0 & 1 \\
\hline FRENCH & $\begin{array}{l}\text { 1: municipality belongs to French } \\
\text { speaking part of Switzerland; 0: else }\end{array}$ & $\begin{array}{l}\text { dummy } \\
\text { variable }\end{array}$ & 2,612 & 0.299 & 0.458 & 0 & 1 \\
\hline ITALIAN & 1: municipality belongs to Italian & dummy & 2,612 & 0.074 & 0.261 & 0 & 1 \\
\hline
\end{tabular}




\begin{tabular}{|c|c|c|c|c|c|c|c|}
\hline Variable name & Variable description & unit & observations & Mean & Std. dev. & $\min$ & $\max$ \\
\hline & speaking part of Switzerland; 0: else & variable & & & & & \\
\hline CATHOLICS & $\begin{array}{l}\text { 1: share of Catholics in } \\
\text { the municipality exceeds } 70 \% \text {; } 0 \text { : else }\end{array}$ & $\begin{array}{l}\text { dummy } \\
\text { variable }\end{array}$ & 2,612 & 0.260 & 0.439 & 0 & 1 \\
\hline CREEDLESS & Share of people without religious affiliation & percent & 2,612 & 8.830 & 5.411 & 0 & 37.240 \\
\hline MUSLIMS 2000 & Share of Muslims in the population in 2000 & percent & 2,612 & 2.224 & 2.662 & 0 & 16.766 \\
\hline MUSLIMS 2010 & $\begin{array}{l}\text { Share of people with Islamic country } \\
\text { citizenship in } 2010\end{array}$ & percent & 2,485 & 1.083 & 1.593 & 0 & 14.77 \\
\hline EDUCATION 1 & $\begin{array}{l}\text { Share of people aged } 25-64 \text { with lower secondary } \\
\text { educational level as highest level } \\
\text { or missing education information }\end{array}$ & percent & 2,612 & 27.714 & 9.314 & 0 & 98.936 \\
\hline CRIME & $\begin{array}{l}\text { Number of criminal acts according to the } \\
\text { Criminal Code per } 1,000 \text { residents }\end{array}$ & $\begin{array}{l}\text { number per } \\
1,000 \text { residents }\end{array}$ & 2,606 & 35.662 & 32.030 & 0 & 701 \\
\hline SVP & $\begin{array}{l}\text { Share of SVP votes (Swiss People's Party) } \\
\text { in the last Parliament voting (2007) }\end{array}$ & percent & 2,601 & 31.945 & 15.001 & 0 & 91.300 \\
\hline TURNOUT & $\begin{array}{l}\text { Share of voted people on the total population } \\
\text { with voting rights }\end{array}$ & percent & 2,612 & 54.651 & 7.536 & 26.667 & 82.759 \\
\hline MIGRATION BALANCE & $\begin{array}{l}\text { Difference between inflows and outflows } \\
\text { in the population }\end{array}$ & 1,000 residents & 2,612 & 0.037 & 0.183 & -0.146 & 6.928 \\
\hline AGE 0-19 & Share of population aged 0-19 & percent & 2,564 & 22.237 & 3.925 & 0 & 43.900 \\
\hline
\end{tabular}




\begin{tabular}{|c|c|c|c|c|c|c|c|}
\hline Variable name & Variable description & unit & observations & Mean & Std. dev. & $\min$ & $\max$ \\
\hline AGE 20-39 & Share of population aged $20-39$ & percent & 2,564 & 23.754 & 3.569 & 0 & 41.860 \\
\hline AGE 40-59 & Share of population aged $40-59$ & percent & 2,564 & 31.109 & 3.112 & 18.180 & 50.180 \\
\hline AGE $60+$ & Share of population aged 60 and over & percent & 2,564 & 22.900 & 5.175 & 5.84 & 75.00 \\
\hline
\end{tabular}


Table A.2: Robustness analysis with alternative estimation methods

\begin{tabular}{lll}
\hline \hline Variable & $\begin{array}{l}\text { Minimum chi-square } \\
\text { logit method }\end{array}$ & $\begin{array}{l}\text { Fractional logit } \\
\text { regression }\end{array}$ \\
\hline Constant & $0.117(0.67)$ & $-1.720(-4.51)$ \\
PERIPHERY & $0.066^{* * *}(4.28)$ & $0.129^{* * *}(3.81)$ \\
RURAL & $0.094^{* * *}(4.81)$ & $0.169^{* * *}(4.64)$ \\
GERMAN & $0.399^{* * *}(19.65)$ & $0.487^{* * *}(23.67)$ \\
ITALIAN & $0.703^{* * *}(26.24)$ & $0.620^{* * *}(19.35)$ \\
RHAETO-ROMANIC & $-0.212^{* * *}(-2.73)$ & $-0.096(-1.57)$ \\
RELIGION MIX & $-0.028^{* *}(-2.09)$ & $-0.059^{* * *}(-3.68)$ \\
EDUCATION 1 & $0.028^{* * *}(26.57)$ & $0.023^{* * *}(14.74)$ \\
EDUCATION 2 & $0.030^{* * *}(23.62)$ & $0.024^{* * *}(12.91)$ \\
WOMEN & $-0.047^{* * *}(-22.08)$ & $-0.013^{* * *}(-2.59)$ \\
UNEMPLOYMENT & $0.011^{* *}(2.07)$ & $-0.002(-0.35)$ \\
INCOME & $-0.025^{* * *}(-3.19)$ & $-0.005(-0.35)$ \\
CRIME & $-0.001^{* * *}(-3.90)$ & $-0.0003(-0.96)$ \\
MIGRATION BALANCE & $-0.035^{* * *}(-8.04)$ & $-0.112^{* * *}(-4.10)$ \\
TERTIARY & $-0.002^{* * *}(-6.78)$ & $-0.003^{* * *}(-6.94)$ \\
MUSLIMS 2000 & $0.006^{* *}(2.12)$ & $0.006^{*}(1.87)$ \\
AGE 0-19 & $0.014^{* * *}(7.17)$ & $0.013^{* * *}(5.47)$ \\
AGE 20-39 & $-0.014^{* * *}(-7.21)$ & $0.005^{*}(1.69)$ \\
AGE 40-59 & $0.011^{* * *}(4.43)$ & $0.009^{* * *}(2.61)$ \\
\hline Observations & 2,557 & 2,558 \\
$R^{2}$ & 0.76 & \\
Adj. $R^{2}$ & 0.76 & \\
F-Statistic & 457.23 & \\
\hline \hline
\end{tabular}

Notes: t-values / z-values in parentheses. The fractional logit regression is estimated using robust standard errors. *** indicates $1 \%$ significance level, ** indicates $5 \%$ significance level, ${ }^{*}$ indicates $10 \%$ significance level. 
Table A.3: Regression results (WLS), dependent variable: SVP vote share

\begin{tabular}{llr}
\hline \hline Variable & Coefficient & t-value \\
\hline Constant & 40.499 & 6.30 \\
PERIPHERY & $1.337^{* *}$ & 2.28 \\
RURAL & $2.558^{* * *}$ & 3.46 \\
GERMAN & $8.622^{* * *}$ & 11.27 \\
ITALIAN & $-10.145^{* * *}$ & -9.96 \\
RHAETO-ROMANIC & $6.535^{* *}$ & 2.23 \\
RELIGION MIX & $2.285^{* * *}$ & 4.56 \\
EDUCATION 1 & 0.059 & 1.46 \\
EDUCATION 2 & $0.462^{* * *}$ & 9.59 \\
WOMEN & $-0.673^{* * *}$ & -8.35 \\
UNEMPLOYMENT & $0.984^{* * *}$ & 4.73 \\
INCOME & $0.803^{* * *}$ & 2.71 \\
CRIME & -0.011 & -1.53 \\
MIGRATION BALANCE & 0.183 & 1.14 \\
TERTIARY & -0.016 & -1.17 \\
MUSLIMS 2000 & $0.610^{* * *}$ & 5.83 \\
AGE 0-19 & $0.356^{* * *}$ & 4.73 \\
AGE 20-39 & 0.037 & 0.52 \\
AGE 40-59 & $0.393^{* * *}$ & 4.07 \\
\hline Observations & 2,546 & \\
$R^{2}$ & 0.82 & \\
Adj. $R^{2}$ & 0.82 & \\
F-Statistic & 643.26 & \\
\hline \hline
\end{tabular}

Notes: *** indicates $1 \%$ significance level, $* *$ indicates $5 \%$ significance level, * indicates $10 \%$ significance level. 
Table A.4: Regression results (WLS) for the estimation sample without merged municipalities, dependent variable: APPROVAL

\begin{tabular}{|c|c|c|c|c|c|c|}
\hline Variable & (1) & $(2)$ & $(3)$ & $(4)$ & $(5)$ & $(5 a)$ \\
\hline \multirow[t]{2}{*}{ Constant } & 1.034 & 1.250 & 0.654 & 0.973 & 0.733 & 0.729 \\
\hline & $(4.12)$ & $(7.42)$ & $(4.14)$ & $(5.89)$ & $(4.34)$ & $(4.13)$ \\
\hline \multirow[t]{2}{*}{ PERIPHERY } & $0.124^{* * *}$ & $0.159^{* * *}$ & $0.140^{* * *}$ & $0.126^{* * *}$ & $0.081^{* * *}$ & $0.076^{* * *}$ \\
\hline & $(6.45)$ & $(10.12)$ & $(9.36)$ & $(8.17)$ & $(5.15)$ & $(4.75)$ \\
\hline \multirow[t]{2}{*}{ RURAL } & $0.418^{* * *}$ & $0.161^{* * *}$ & $0.123^{* * *}$ & $0.135^{* * *}$ & $0.083^{* * *}$ & $0.082^{* * *}$ \\
\hline & $(14.71)$ & $(8.00)$ & $(6.47)$ & $(6.93)$ & $(4.23)$ & $(4.06)$ \\
\hline \multirow[t]{2}{*}{ GERMAN } & $0.164^{* * *}$ & $0.364^{* * *}$ & $0.247^{* * *}$ & $0.365^{* * *}$ & $\mathbf{0 . 3 9 3 ^ { * * * }}$ & $0.398^{* * *}$ \\
\hline & 11.64) & $(21.92)$ & $(12.82)$ & $(18.90)$ & $(19.21)$ & $(19.62)$ \\
\hline \multirow[t]{2}{*}{ ITALIAN } & $0.506^{* * *}$ & $0.550 * * *$ & $0.673^{* * *}$ & $0.571^{* * *}$ & $0.598^{* * *}$ & $\mathbf{0 .} 601^{* * *}$ \\
\hline & $(10.24)$ & $(18.20)$ & $(23.01)$ & $(19.61)$ & $(19.62)$ & $(19.41)$ \\
\hline \multirow[t]{2}{*}{ RHAETO-ROMANIC } & $-0.340^{* *}$ & $-0.346^{* * *}$ & $-0.423^{* * *}$ & $-0.337^{* * *}$ & $-0.259^{* * *}$ & $-0.258^{* * *}$ \\
\hline & $(-2.41)$ & $(-4.13)$ & $(-5.47)$ & $(-4.20)$ & $(-3.27)$ & $(-3.22)$ \\
\hline \multirow[t]{2}{*}{ WOMEN } & & $-0.050^{* * *}$ & $-0.041^{* * *}$ & $-0.038^{* * *}$ & $-0.046^{* * *}$ & $-0.047^{* * *}$ \\
\hline & & $(-23.06)$ & $(-23.56)$ & $(-20.98)$ & $(-21.61)$ & $(-22.03)$ \\
\hline \multirow[t]{2}{*}{ EDUCATION 1} & & $0.028^{* * *}$ & $0.027 * * *$ & $0.025^{* * *}$ & $0.027^{* * *}$ & $0.028^{* * *}$ \\
\hline & & $(26.24)$ & $(25.20)$ & $(24.61)$ & $(25.88)$ & $(26.50)$ \\
\hline \multirow[t]{2}{*}{ EDUCATION 2} & & $0.032^{* * *}$ & $0.025^{* * *}$ & $0.028^{* * *}$ & $0.029^{* * *}$ & $0.030^{* * *}$ \\
\hline & & $(24.43)$ & $(20.08)$ & $(23.83)$ & $(23.34)$ & $(22.88)$ \\
\hline \multirow[t]{2}{*}{ UNEMPLOYMENT } & & $0.023^{* * *}$ & $0.010^{*}$ & $0.010^{*}$ & $0.012^{* *}$ & $0.013^{* *}$ \\
\hline & & $(4.35)$ & $(1.80)$ & $(1.84)$ & $(2.20)$ & $(2.42)$ \\
\hline \multirow[t]{2}{*}{ INCOME } & & $-0.032^{* * *}$ & $-0.036^{* * *}$ & $-0.016^{* *}$ & $-0.022^{* * *}$ & $-0.020^{* * *}$ \\
\hline & & $(-4.25)$ & $(-4.83)$ & $(-2.24)$ & $(-2.90)$ & $(-2.58)$ \\
\hline \multirow[t]{2}{*}{ CRIME } & & $-0.002^{* * *}$ & $-0.002^{* * *}$ & $-0.001^{* * *}$ & $-0.001^{* * *}$ & $-0.001^{* * *}$ \\
\hline & & $(-13.12)$ & $(-12.96)$ & $(-7.10)$ & $(-2.94)$ & $(-3.29)$ \\
\hline \multirow[t]{2}{*}{ RELIGION MIX } & & & & $-0.037^{* * *}$ & $-0.045^{* * *}$ & $-0.043^{* * *}$ \\
\hline & & & & $(-2.74)$ & $(-3.36)$ & $(-3.20)$ \\
\hline \multirow[t]{2}{*}{ CREEDLESS } & & $-0.003^{* * *}$ & & & & \\
\hline & & $(-2.84)$ & & & & \\
\hline \multirow[t]{2}{*}{ PROTESTANTS } & & & $0.046^{* *}$ & & & \\
\hline & & & $(2.36)$ & & & \\
\hline \multirow[t]{2}{*}{ CATHOLICS } & & & $0.047^{* * *}$ & & & \\
\hline & & & $(2.81)$ & & & \\
\hline \multirow[t]{2}{*}{ MUSLIMS 2000} & & & 0.002 & $0.006^{* *}$ & $0.008^{* * *}$ & \\
\hline & & & $(0.72)$ & $(2.17)$ & $(2.89)$ & \\
\hline \multirow[t]{2}{*}{ MUSLIMS 2010} & & & & & & $0.010^{* * *}$ \\
\hline & & & & & & $(2.59)$ \\
\hline MIGRATION BALANCE & & & & $-0.047^{* * *}$ & $-0.035^{* * *}$ & $-0.033^{* * *}$ \\
\hline
\end{tabular}




\begin{tabular}{|c|c|c|c|c|c|c|}
\hline Variable & $(1)$ & $(2)$ & (3) & $(4)$ & $(5)$ & $(5 \mathrm{a})$ \\
\hline & & & & $(-11.76)$ & $(-8.29)$ & $(-7.61)$ \\
\hline \multirow[t]{2}{*}{ TERTIARY SECTOR } & & & & $-0.003^{* * *}$ & $-0.002^{* * *}$ & $-0.002^{* * *}$ \\
\hline & & & & $(-8.21)$ & $(-5.54)$ & $(-5.36)$ \\
\hline \multirow[t]{2}{*}{ AGE 0-19 } & & & & & $0.013^{* * *}$ & $0.014^{* * *}$ \\
\hline & & & & & $(6.65)$ & $(6.87)$ \\
\hline \multirow[t]{2}{*}{ AGE 20-39 } & & & & & $-0.014^{* * *}$ & $-0.014^{* * *}$ \\
\hline & & & & & $(-7.39)$ & $(-7.28)$ \\
\hline \multirow[t]{2}{*}{ AGE 40-59 } & & & & & $0.009 * * *$ & $0.009^{* * *}$ \\
\hline & & & & & $(3.54)$ & $(3.43)$ \\
\hline \multirow[t]{2}{*}{ FOREIGNERS } & & & $-0.003^{* * *}$ & & & \\
\hline & & & $(-3.05)$ & & & \\
\hline \multirow[t]{2}{*}{ SVP } & & & $0.010^{* * *}$ & & & \\
\hline & & & $(18.68)$ & & & \\
\hline \multirow[t]{2}{*}{ TURNOUT } & & $0.004^{* * *}$ & & & & \\
\hline & & $(4.11)$ & & & & \\
\hline Observations & 2,449 & 2,448 & 2,437 & 2,448 & $\mathbf{2}, 431$ & $\mathbf{2}, 352$ \\
\hline$R^{2}$ & 0.19 & 0.73 & 0.77 & 0.75 & 0.76 & 0.76 \\
\hline Adjusted $R^{2}$ & 0.19 & 0.73 & 0.77 & 0.75 & 0.76 & 0.76 \\
\hline F-statistic & 115.88 & 509.17 & 500.68 & 490.34 & 433.52 & 414.66 \\
\hline
\end{tabular}

Notes: t-values in parentheses. ${ }^{* * *}$ indicates $1 \%$ significance level, ${ }^{* *}$ indicates $5 \%$ significance level, ${ }^{*}$ indicates $10 \%$ significance level. For data description s. Table A.1. 
Table A.5: Overview of xenophobic popular initiatives between 1970 and 2009

\begin{tabular}{|c|c|c|c|}
\hline Date & Title & Description / goals & Outcome (yeas) \\
\hline $06 / 07 / 1970$ & $\begin{array}{l}\text { Popular initiative } \\
\text { 'Against foreign infiltration' }\end{array}$ & $\begin{array}{l}\text { Measures against foreign infiltration } \\
\text { (relating to population and economy) by fixing of } \\
\text { maximal share of foreigners to } 10 \% \text { (Genf: } 25 \% \text { ); } \\
\text { worse conditions for foreigners by job cuts }\end{array}$ & $46 \%$ \\
\hline $10 / 20 / 1974$ & $\begin{array}{l}\text { Popular initiative 'Against foreign infiltration } \\
\text { and overcrowding of Switzerland' }\end{array}$ & $\begin{array}{l}\text { Fixing of maximal number (for Switzerland: } 500,000 \text { ) } \\
\text { and share of foreigners } \\
\text { (for cantons excepting Genf: } 12 \% \text {; Genf: } 25 \% \text { ) } \\
\text { as well as limitation of naturalizations by } 4,000 \text { per year }\end{array}$ & $34.2 \%$ \\
\hline $03 / 13 / 1977$ & $\begin{array}{l}\text { Popular initiative 'Fourth initiative } \\
\text { against foreign infiltration' }\end{array}$ & $\begin{array}{l}\text { Fixing of maximal share of } \\
\text { settled foreigners to } 12.5 \\
\% \text { on entire Swiss population }\end{array}$ & $29.5 \%$ \\
\hline $03 / 13 / 1977$ & $\begin{array}{l}\text { Popular initiative } \\
\text { 'For a limitation of naturalizations' }\end{array}$ & $\begin{array}{l}\text { Limitation of naturalizations to } \\
4,000 \text { naturalizations per year }\end{array}$ & $33.8 \%$ \\
\hline $05 / 20 / 1984$ & $\begin{array}{l}\text { Popular initiative } \\
\text { 'Against the sale of homeland' }\end{array}$ & $\begin{array}{l}\text { Property sale only on persons } \\
\text { within Switzerland }\end{array}$ & $48.9 \%$ \\
\hline $12 / 04 / 1988$ & $\begin{array}{l}\text { Popular initiative } \\
\text { 'For the limitation of immigration' }\end{array}$ & $\begin{array}{l}\text { Fixing of maximal number of immigrants and } \\
\text { grants of residence right } \\
\text { by maximal number of migrants }\end{array}$ & $32.7 \%$ \\
\hline $12 / 01 / 1996$ & $\begin{array}{l}\text { Popular initiative } \\
\text { 'Against the illegal immigration' }\end{array}$ & $\begin{array}{l}\text { Refusal of asylum rights for } \\
\text { illegal immigrants }\end{array}$ & $46.3 \%$ \\
\hline $09 / 24 / 2000$ & $\begin{array}{l}\text { Popular initiative } \\
\text { 'For a regulation of immigration' }\end{array}$ & $\begin{array}{l}\text { Fixing of maximal share of foreigners to } \\
18 \% \text { on the entire population }\end{array}$ & $36.2 \%$ \\
\hline $11 / 24 / 2002$ & $\begin{array}{l}\text { Popular initiative } \\
\text { 'Against abuse of the asylum right' }\end{array}$ & $\begin{array}{l}\text { Refusal of asylum rights for immigrants } \\
\text { from a secure third country }\end{array}$ & $49.9 \%$ \\
\hline $06 / 01 / 2008$ & $\begin{array}{l}\text { Popular initiative } \\
\text { 'For democratic naturalizations' }\end{array}$ & $\begin{array}{l}\text { Authority of municipalities } \\
\text { in naturalization requests }\end{array}$ & $36.2 \%$ \\
\hline $11 / 29 / 2009$ & $\begin{array}{l}\text { Popular initiative } \\
\text { 'Against the building of minarets' }\end{array}$ & $\begin{array}{l}\text { Ban of minaret building in } \\
\text { Switzerland }\end{array}$ & $57.5 \%$ \\
\hline
\end{tabular}

